\title{
ETLA
}

\section{ELINKEINOELÄMÄN TUTKIMUSLAITOS}

THE RESEARCH INSTITUTE OF THE FINNISH ECONOMY

Lönnrotinkatu 4 B 00120 Helsinki Finland Tel. 358-9-609 900

Telefax 358-9-601 753 World Wide Web: http://www.etla.fi/

\section{Keskusteluaiheita - Discussion papers}

No. 1092

\author{
Pekka IImakunnas* - Mika Maliranta*
}

\section{AGING, LABOR TURNOVER AND}

\section{FIRM PERFORMANCE***}

* Helsinki School of Economics and HECER

P.O. Box 1210 FIN-00101 Helsinki Finland, E-mail: pekka.ilmakunnas@hse.fi

** The Research Institute of the Finnish Economy (ETLA)

Lönnrotinkatu 4 B FIN-00120 Helsinki Finland, E-mail: mika.maliranta@etla.fi

*** An earlier version of this paper was circulated under the title "Deferred retirement curbs business profits?". We are thankful to many individuals at Statistics Finland, and especially to Satu Nurmi and Elias Einiö for their guidance regarding the properties of the data. The data set is publicly available for research purposes, subject to terms and conditions of confidentiality, at the research laboratory of the Business Structures unit of Statistics Finland. Please contact the Research Laboratory of the Business Structures Unit, Statistics Finland, FIN-00022, Finland, for access to these data. We have benefited from the comments of Roope Uusitalo and seminar participants at the Government Institute of Economic Research (Helsinki), Nordic Summer Institute in Labor Economics in Uppsala, EEA Congress in Vienna, CAED Conference in Chicago, Annual Meeting of the Finnish Society for Economic Research in Helsinki, World Aging and Generations Congress in StGallen, and Workshop on Labor Turnover and Firm Performance, Helsinki. Financial support from the Yrjö Jahnsson Foundation is gratefully acknowledged. The SAS and Stata codes used in this study are available from the authors upon request. 
ILMAKUNNAS, Pekka - MALIRANTA, Mika, AGING, LABOR TURNOVER AND FIRM PERFORMANCE. Helsinki: ETLA, Elinkeinoelämän Tutkimuslaitos, The Research Institute of the Finnish Economy, 2007, 40 p. (Keskusteluaiheita, Discussion papers, ISSN 0781-6847; No. 1092).

ABSTRACT: We study whether older workers are costly to firms. Our estimation equations are derived from a variant of the decomposition methods frequently used for measuring micro-level sources of industry productivity growth. By using comprehensive linked employeremployee data from the Finnish business sector, we study the productivity and wage effects, and hence the profitability effects, of hiring and separation of younger and older workers. The evidence shows that separations of older workers are profitable to firms, especially in the manufacturing ICT-industries. Robustness checks include the use of regional labor supply and other variables as instruments for the potential endogeneity of the labor flows.

JEL-code: C43, J23, J24, J63, M51

Keywords: aging, productivity, wage, profits, hiring, separation, employer-employee data

ILMAKUNNAS, Pekka - MALIRANTA, Mika, AGING, LABOR TURNOVER AND FIRM PERFORMANCE. Helsinki: ETLA, Elinkeinoelämän Tutkimuslaitos, The Research Institute of the Finnish Economy, 2007, 40 s. (Keskusteluaiheita, Discussion papers, ISSN 0781-6847; No. 1092).

TIIVISTELMÄ: Tutkimuksessa selvitetään heikentävätkö ikääntyneet työntekijät yrityksen kannattavuutta. Estimoidut yhtälöt on johdettu käyttämällä lähtökohtana erästä tuottavuuden dekomponointikaavan versiota. Samantyyppisiä dekomponointikaavoja on usein käytetty tutkittaessa toimialan tuottavuuden kasvun yritys- ja toimipaikkatason lähteitä. Kattavia yhdistettyjä työntekijä-työnantaja-aineistoja käyttämällä tutkitaan, miten nuorten ja vanhempien työntekijöiden rekrytoinnit ja irtisano(utu)miset vaikuttavat yrityksen tuottavuuteen ja palkkatasoon, ja tätä kautta kannattavuuteen. Tulosten perusteella vanhempien työntekijöiden irtisano(utu)miset ovat yritykselle taloudellisesti kannattavia, erityisesti tieto- ja viestintäteknologiaa intensiivisesti käyttävillä teollisuusaloilla. Herkkyysanalyysissä on käytetty työntekijöiden alueellisista tarjontaa ja kysyntää koskevia muuttujia instrumentteina. Niiden avulla on pyritty korjaamaan mahdollista harhaa, jonka voi aiheuttaa tuottavuuden muutoksen vaikutus työntekijävirtoihin.

JEL-koodi: C43, J23, J24, J63, M51

Avainsanat: ikääntyminen, tuottavuus, palkka, voitot, rekrytoinnit, irtisano(utu)miset, työntekijä-työnantaja-aineisto 


\section{Introduction}

Increasing average age of the work force poses difficult challenges both to firms and the whole society. As a result of changes in the age structure, an increasing share of firms' employees is in higher age groups. Changes in the available labor supply also imply that firms may not be able to hire as many young employees as they wish. On the other hand, pressures on the sustainability of pension systems have led governments to find ways of getting people to lengthen their working lives. Efforts have been made to reduce incentives of using early retirement channels, as the actual retirement age in many countries falls clearly below the mandatory retirement age (OECD, 2006). There have been demands for raising the mandatory retirement age, but also for extending the subjective right to continue working. Most notably, in the US mandatory retirement age rules have been eliminated in most private sector jobs as a result of anti-age-discrimination laws introduced in the 1960s. There have been policy changes also in some European countries. In the UK, for example, workers have the right to request to stay on the job after the mandatory retirement age. In some countries the subjective right has been extended, for example in Finland to 68 years. These developments will in turn still increase the average age of the work force.

From the firms' point of view, an important issue is how to deal with the aging work force. To illustrate the firms' dilemmas, we can consider the following examples. The Swedish hightech firm Ericsson recently decided to offer redundancy to workers in the 35 to 50 age group and having at least 6 years' seniority. This was based on the firm's view that staff turnover was too low and the age structure was becoming disadvantageous. ${ }^{1}$ A confidential Wal-Mart memorandum leaked to the media in 2005 stated that aging workforce and increasing tenure caused an unacceptable growth in benefit costs. ${ }^{2}$ These age-related increases in labor costs are related to health care costs and seniority-based pay systems, which are common in many firms. ${ }^{3}$ On the other hand, there are examples where firms have been able to prosper by keeping or hiring older workers or have experienced disruption of productivity when older employees with tacit knowledge have left. The advocates of older employees emphasize that lower turnover and higher experience may compensate age-related losses in working capacity (e.g. AARP, 2005). The role of aging employees for the performance of firms may clearly be an industry-specific issue. 
We examine the connection of aging work force to firm performance by using information on the hiring and separation of employees. Our approach is to disaggregate labor flows to and from firms by age to three groups, “young” (30 or less), “middle-aged” (31 to 50), and “old” (over 50). We emphasize that the labels “young” and "old” are used just for illustrative purposes and refer to relative age. We show that firm-level labor productivity change can be decomposed to the effects of the hiring and separation rates of the age groups and to the effect of productivity growth of those workers in different age groups who are staying in the firm. Our decomposition bears a resemblance to the kind of decompositions used frequently to decompose industry-level productivity change to the impacts of entry and exit of firms, and productivity growth in continuing firms. A commonly used formula has been suggested by Foster et al. (2001), but our formulation is closer to the formulas proposed by Maliranta (1997), Vainiomäki (1999) and more recently by Diewert and Fox (2005). In contrast to the industry studies where firm productivities are observed, in our case the productivity of the individual employees within firms cannot be measured. However, the decomposition leads to a simple estimation equation where the parameters have the interpretation of relative productivity levels of the different employee groups. A similar decomposition can be made for firm wage growth. Combining the two decompositions, we also obtain an equation for firm profitability change, which is the main interest of this paper. To be able to perform the analysis we need detailed and comprehensive linked employer-employee data. We use the FLEED (Finnish Longitudinal Employer-Employee Data) data set of Statistics Finland that covers basically all firms in the country and all of their employees. The decompositions relate to performance change in the two-year intervals 1995-97, 1997-99, 1999-2001, and 2001-2003.

Our results show that there are indeed differences between the age groups in their relative productivity and wage levels, and hence the age structure of employees may have impacts on firm performance. In particular, we find that the outflow of older workers has an economically strong positive effect on the firms' profitability, especially in the manufacturing ICT industries. This is mainly because before separation the productivity level of newly hired older workers is substantially below that of the average worker in the firm but their wage level is, however, reasonably close to the average. Other labor flows instead have generally more neutral effects on firms' profits. On the hiring side for instance, the relative wage levels of older workers correspond to their relative productivity levels so that the inflow of older workers does not change the profitability of the firms. Separated young workers have considerably higher productivity levels than the average worker or separated older workers. This is 
most likely caused by high-productivity employees having more job opportunities and being more likely to switch jobs. But the wage levels of the separated young workers are also relatively high, which means that outflow of young workers does not harm firms' profitability significantly. To control for the fact that the labor flows are to a large extent chosen by the firm, we instrument the flows by variables that describe either exogenous changes in the supply in the local labor market (to instrument hiring), and changes in local labor demand or the characteristics of the existing work force of the firms (to instrument separation). The instrumental variable estimation results provide further support to our main findings.

The structure of the paper is as follows. In section 2 we provide a theoretical discussion. In section 3 we describe the decomposition of the growth in productivity, wage, and profitability to the impacts of the labor flows. In section 4 we describe the data set and present the estimation results. Section 5 concludes the paper with some suggestions for further research.

\section{Previous research}

It is not immediately clear, what is an optimal age structure or optimal turnover rate for a firm. Young workers are less experienced, but usually have longer and more up-to-date education. Older workers may have passed the peak of their physical productivity, but may be able to compensate for it with their long experience. The decision on the age structure also depends on labor supply. The availability of workers of different ages may rapidly change, since the younger age cohorts are smaller than the old ones. This may encourage firms to keep their aging employees. The wage structure also has an impact on the firms' choices, since it is the productivity and wage effects together that determine the impact of the age structure on firm performance. Wages often have seniority-based elements. There are several alternative explanations for this: there is wage growth with accumulation of human capital through experience, older workers as insiders have more bargaining power in the wage negotiations, employment protection legislation favors older employees, and there can be deferred payments elements in wage setting (see e.g. Lazear, 1990). According to the deferred payments argument (Lazear, 1979; Hutchens, 1986), lower pay of the employees in their early career is repaid by the firm in the form of wage that exceeds productivity in the later career. While Lazear uses this feature of wage determination to explain the existence of mandatory retire- 
ment, it can also give an explanation for differences between age groups in the employers' incentives to initiate separations. Pension systems may give an additional reason for this kind of relationship between productivity and pay. In defined benefits pension systems the pension is typically defined as a fraction, based on the length of the employment relationship, of the last year's income (so-called final salary pension) or the last few years' income. This gives incentives for employees to bargain for a back-loaded wage.

Our paper relates the discussion on deferred payments and separation incentives to two other fields of literature. One is the connection of age and productivity, which has been extensively discussed in psychology and physiology (e.g. Kanazawa, 2003), and in recent years also in economics. Since individual-level productivity measures are available only in very special cases, a field of research has emerged, where linked employer-employee data sets are used for analyzing the impact of work force characteristics, like average age or shares of employees in different age groups, on plant- or firm-level productivity and wage (e.g. Hellerstein et al., 1999; Hellerstein \& Neumark, 2004; Ilmakunnas \& Maliranta, 2005; Maliranta \& Ilmakunnas, 2005; Daveri \& Maliranta, 2007). A drawback of this line of studies is that they do not pay much attention to how the structure of the work force is determined, although in some studies the work force age (and other characteristics) have been instrumented (Aubert \& Crépon, 2003; Malmberg et al., 2005; Daveri \& Maliranta, 2007).

The research with linked data sets is mostly concerned with comparisons of productivity and wage profiles to test different theories of wage formation. The results in this literature are not quite conclusive, but there is some evidence from various countries that firm productivity tends to have an inverted U-shaped relationship with age, while average wage is increasing in age (for a survey, see Skirbekk, 2004). Evaluation of the performance of firms has not been a central issue in this context. We will also utilize linked data, but will extend the analysis to directly examining how the age structure of the work force changes through the inflow and outflow of labor input and how the flows subsequently influence firm profitability.

Another strand of research that our paper is related to is the connection between labor turnover and firm performance. Much of this work has appeared in the field of human resource management, where the analysis is often restricted to special data sets with emphasis on quit behavior and the firms' policies to control it. Traditionally, the negative aspects of this kind of turnover have been emphasized. In the parlance of the management literature (e.g. Dalton et 
al., 1982), separation is dysfunctional, when those high-productivity workers whom the organization would like to keep, are leaving. This involves costs in the form of rehiring and training, but also less directly in the form of disruption of informal communication structures. Costs may also be caused by employer-initiated separations in the form of firing costs. Also the traditional labor economics view is that quitting needs to be controlled for example with wage policy since otherwise the employees would not stay long enough to accumulate specific human capital. There are also models for optimizing hiring and separation to maximize profits (e.g. Hamermesh \& Pfann, 1996). In these models it is assumed that both hiring and firing have negative consequences through adjustment costs.

In contrast to the traditional view, from the 1980's management research has emphasized that labor turnover can also be functional, i.e. in the interest of the organization. This can happen e.g. when low productivity workers quit or their separation from the firm is initiated by the employer. Replacing the leavers by new workers also brings new ideas and knowledge to the firm. In economics, the positive influences of turnover have been emphasized more formally in models where the search and matching process allocates workers to their best uses in firms (e.g. Jovanovic, 1979). Worker flows and the matching process may be particularly important for productivity when technological change is rapid (see e.g. Aghion \& Howitt, 1996).

The existing empirical evidence on the effect of various measures of labor turnover on firm performance, measured by productivity or profitability, is somewhat mixed. ${ }^{4}$ A drawback in this field of work is that most of the research is concerned with separations, often only with quits. The hiring side of turnover has received much less attention, except indirectly, since separations often lead to a need for rehiring. There are, however, a few studies that have examined the separate effects of hiring and separation on performance; Bingley and Westergaard-Nielsen (2004), Ilmakunnas et al. (2005), and Siebert et al. (2006) using firm or plant data, and Blakemore and Hoffman (1989) with aggregate data. Further, there is hardly any work that studies the impacts of turnover of different types of employees. ${ }^{5}$ If all employees were perfect substitutes, worker turnover would be dysfunctional since it would just cause costs without having a positive impact on productivity. The only necessary turnover would be such that is needed for expanding or reducing the total size of the labor input. However, if there is a connection between e.g. the age structure of the work force and performance, it is the inflow and outflow of different types of employees that the firms should control to optimize the work force structure. In practice, the age structure of the employees changes when 
the average age level of the inflow differs from that of the outflow. The optimal age mix of employees, and therefore the optimal inflow and outflow of different age groups, is based on the relative productivities and wages of the age groups. The choice of the age mix is constrained by legal limits on layoffs, availability of different types of employees (i.e., local labor supply), and differences in the quit propensities of different employee types.

\section{Decomposition and estimation of firm performance}

We assume that a firm's labor force consists of $\mathrm{M}$ different age groups (cohorts) $j=1, \ldots, M$, and that the firm's output (value added) in period 1 can be defined as the sum of outputs of all the worker groups:

$$
Y_{1}=\sum_{j}^{M} Y_{1 j}
$$

The firm's labor productivity is the average of labor productivities, weighted by labor shares:

$$
\frac{Y_{1}}{L_{1}}=\sum_{j}^{M} \frac{L_{1 j}}{L_{1}} \frac{Y_{1 j}}{L_{1 j}},
$$

where $L_{1}=\sum_{j}^{M} L_{1 j}$. Each worker age group can further be divided into two subgroups; workers who worked in the previous period 0 and are still working in the firm, i.e., stayers (stay), and those who are working in the firm in year 1 but were not there in period 0, i.e., they were hired after 0 (hire). The firm's labor productivity level can then be expressed as follows:

$$
\frac{Y_{1}}{L_{1}}=\sum_{j}^{M} \frac{L_{1 j, \text { stay }}}{L_{1}} \frac{Y_{1 j \text {,stay }}}{L_{1 j \text {,stay }}}+\sum_{j}^{M} \frac{L_{1 j, \text { hire }}}{L_{1}} \frac{Y_{1 j, \text { hire }}}{L_{1 j, \text { hire }}}
$$

Because the shares of stayers and hired workers add up to one,

$$
\sum_{j}^{M} \frac{L_{1 j, \text { stay }}}{L_{1}}+\sum_{j}^{M} \frac{L_{1 j, \text { hire }}}{L_{1}}=1,
$$

(3) can be written as follows: 


$$
\begin{aligned}
& \frac{Y_{1}}{L_{1}}=\sum_{j}^{M} \frac{L_{1 j, \text { stay }}}{\sum_{1 j} L_{1 j, \text { stay }}} \frac{Y_{1 j, \text { stay }}}{L_{1 j, \text { stay }}}+\sum_{j}^{M} \frac{L_{1 j, \text { hire }}}{L_{1}}\left(\frac{Y_{1 j, \text { hire }}}{L_{1 j, \text { hire }}}-\sum_{j}^{M} \frac{L_{1 j, \text { stay }}}{\sum_{1 j} L_{1 j, \text { stay }}} \frac{Y_{1 j, \text { stay }}}{L_{1 j, \text { stay }}}\right) \\
& =\sum_{j}^{M} \frac{L_{1 j, \text { stay }}}{\sum_{1 j} L_{1 j, \text { stay }}} \frac{Y_{1 j, \text { stay }}}{L_{1 j, \text { stay }}}+\sum_{j}^{M} \frac{L_{1 j, \text { hire }}}{L_{1}}\left(\frac{Y_{1 j, \text { hire }}}{L_{1 j, \text { hire }}}-\frac{Y_{1, \text { stay }}}{L_{1, \text { stay }}}\right)
\end{aligned}
$$

To write the labor productivity level of the firm in period 0 we define a third subgroup, those who were in the firm in period 0 , but are no longer there in period 1, i.e. those who have separated after 0 (sepa). We can write the period 0 productivity in an analogous way to (4):

$$
\begin{aligned}
& \frac{Y_{0}}{L_{0}}=\sum_{j}^{M} \frac{L_{0 j, \text { stay }}}{\sum_{0 j} L_{0 j, \text { stay }}} \frac{Y_{0 j, \text { stay }}}{L_{0 j, \text { stay }}}+\sum_{j}^{M} \frac{L_{0 j, \text { sepa }}}{L_{0}}\left(\frac{Y_{0 j, \text { sepa }}}{L_{0 j, \text { sepa }}}-\sum_{j}^{M} \frac{L_{0 j, \text { stay }}}{\sum_{0 j} L_{0 j, \text { stay }}} \frac{Y_{0 j, \text { stay }}}{L_{0 j, \text { stay }}}\right) \\
& =\sum_{j}^{M} \frac{L_{0 j, \text { stay }}}{\sum_{0 j} L_{0 j, \text { stay }}} \frac{Y_{0 j, \text { stay }}}{L_{0 j, \text { stay }}}+\sum_{j}^{M} \frac{L_{0 j, \text { sepa }}}{L_{0}}\left(\frac{Y_{0 j, \text { sepa }}}{L_{0 j, \text { sepa }}}-\frac{Y_{0 j, \text { stay }}}{L_{0 j, \text { stay }}}\right)
\end{aligned}
$$

Of course it holds that

$$
\sum_{j}^{M} L_{0 j, \text { stay }}=\sum_{j}^{M} L_{1 j, \text { stay }}
$$

We are interested in labor productivity growth, i.e., the growth of productivity level between periods 0 and 1, i.e.

$$
\Delta \frac{Y}{L}=\frac{Y_{1}}{L_{1}}-\frac{Y_{0}}{L_{0}}
$$

We define the worker age groups in such a way that none of the staying workers changes her group between periods 0 and 1, i.e.,

$L_{0 j, \text { stay }}=L_{1 j \text {,stay }}$ (and therefore $\frac{L_{1 j \text {,stay }}}{\sum_{0 j} L_{1 j, \text { stay }}}=\frac{L_{1 j, \text { stay }}}{\sum_{1 j} L_{1 j, \text { stay }}}$ ) for all $j$. Note that people are, of course, aging over time, but the age groups should be understood as cohorts rather than absolute age groups.

We then obtain ${ }^{6}$ 


$$
\begin{aligned}
& \frac{Y_{1}}{L_{1}}-\frac{Y_{0}}{L_{0}}= \\
& \sum_{j}^{M} \frac{L_{0 j, \text { stay }}}{\sum_{j} L_{0 j, \text { stay }}}\left(\frac{Y_{1 j, \text { stay }}}{L_{1 j, \text { stay }}}-\frac{Y_{0 j, \text { stay }}}{L_{0 j, \text { stay }}}\right)+ \\
& \sum_{j}^{M} \frac{L_{1 j, \text { hire }}}{L_{1}}\left(\frac{Y_{1 j, \text { hire }}}{L_{1 j, \text { hire }}}-\frac{Y_{1, \text { stay }}}{L_{1, \text { stay }}}\right)+ \\
& \sum_{j}^{M} \frac{L_{0 j, \text { sepa }}}{L_{0}}\left(\frac{Y_{0, \text { stay }}}{L_{0, \text { stay }}}-\frac{Y_{0 j, \text { sepa }}}{L_{0 j, \text { sepa }}}\right)
\end{aligned}
$$

The first set of terms on the right-hand side of equation (7) shows the productivity growth "within workers", i.e. the productivity growth that accumulates over time for those who are staying in the firm. It can be interpreted as productivity growth due to the accumulation of human capital through experience. The within worker productivity growth may vary across the age groups, and the total effect is a labor share weighted average of productivity changes in the different groups. A firm has a rapid productivity growth when a large proportion of workers have a high productivity growth rate. These workers may have such human capital that enables them to adopt or innovate more productive techniques. In other words, these workers have dynamic long-run effects on the company's productivity. This effect can be called as Nelson-Phelps effect according to the seminal work by Nelson and Phelps (1966).

The second set of terms indicates the productivity effects of hiring of workers in different age groups. As can be seen from (7), hiring of type $j$ workers has a positive impact on productivity change when these hired workers have a higher productivity level than the average staying workers. Newly hired workers may be more productive than incumbents in period 1 because they have learned more productive techniques when they worked for the previous employer, or have more recent education, for example. Adjustment costs related to the hiring of new employees are implicitly included in our formulation. The relative productivity of the hired workers should therefore be understood as productivity net of adjustment costs.

Finally, the third set of terms indicates the productivity effects of separations of different worker age groups. Quite analogously to the hiring effect, separation of type $j$ workers has a positive effect on productivity change when these workers have a lower productivity level than the average incumbent worker in period 0. Again, the productivity impact of separations is net of adjustment costs. 
The terms of (7) can be turned into growth rates by dividing them by the average productivity level in the periods 0 and 1 . The growth rate is then a close approximation of a more common log-difference, i.e.,

$$
\frac{Y_{1} / L_{1}-Y_{0} / L_{0}}{0.5\left(Y_{1} / L_{1}+Y_{0} / L_{0}\right)} \cong \ln \frac{Y_{1} / L_{1}}{Y_{0} / L_{0}}=d \ln (Y / L)
$$

Besides labor productivity, we can use a similar decomposition for the average wage level in the firm. In this case we just replace $Y$ in the equations above by the wage sum $W$.

Equations (7) and (8), and corresponding equations for wage growth can be used for estimating productivity gaps and wage gaps between age groups. These gaps can be analyzed both on the hiring side and on the separation side. We obtain the following estimation models:

$$
\begin{aligned}
& \frac{\Delta(Y / L)}{\overline{(Y / L)}}=\alpha+\sum_{j}^{M} \beta_{L P, j, h i r e} H R_{j}+\sum_{j}^{M} \beta_{L P, j, \text { sepa }} S R_{j}+\sum_{j}^{M-1} \chi_{L P, j, \text { stay }} S \mathrm{SAYSH}_{j}+\delta^{\prime} \mathbf{Z}+\varepsilon \\
& \frac{\Delta(W / L)}{\overline{(W / L)}}=\alpha+\sum_{j}^{M} \beta_{W, j, \text { hire }} H R_{j}+\sum_{j}^{M} \beta_{W, j, \text { sepa }} S R_{j}+\sum_{j}^{M-1} \chi_{W, j, \text { stay }} \mathrm{STAYSH}_{j}+\delta^{\prime} \mathbf{Z}+\varepsilon
\end{aligned}
$$

where $\overline{(Y / L)}=0.5\left[\left(Y_{0} / L_{0}\right)+\left(Y_{1} / L_{1}\right)\right]$ and $\overline{(W / L)}=0.5\left[\left(W_{0} / L_{0}\right)+\left(W_{1} / L_{1}\right)\right]$ are two period averages in productivity and wage, respectively, $H R_{j}=\frac{L_{1 j, h i r e}}{L_{1}}$ and $S R_{j}=\frac{L_{0 j, \text { sepa }}}{L_{0}}$ are the hiring and separation rates, and $\operatorname{STAYSH}_{j}=\frac{L_{0 j, \text { stay }}}{L_{0, \text { stay }}}\left(=\frac{L_{1 j, \text { stay }}}{L_{1 j, \text { stay }}}\right)$ is the share of staying workers. We have added control variables $\mathrm{Z}$ to account for other exogenous influences on firm productivity, wage, and profits. In the estimations, we use firm panel data, so the equations to be estimated will be indexed with $i$ (firm) and $t$ (period), which are not shown in (9)-(10).

On the hiring side the coefficients of our main interest that will be estimated with equations (9)-(10) have the following interpretations:

$$
\beta_{(Y / L), j, h i r e}=\frac{(Y / L)_{1, j, h i r e}-(Y / L)_{1, \text { stay }}}{\overline{(Y / L)}}
$$




$$
\beta_{(W / L), j, \text { hire }}=\frac{(W / L)_{1, j, \text { hire }}-(W / L)_{1, \text { stay }}}{\overline{(W / L)}},
$$

i.e. they measure the relative productivity and wage, respectively, of hired workers in age group $j$, compared to all staying workers. For the separation side, the estimable coefficients are obtained analogously as

$$
\begin{gathered}
\beta_{(Y / L), j, \text { sepa }}=\frac{(Y / L)_{0, \text { stay }}-(Y / L)_{0, j, \text { sepa }}}{\overline{(Y / L)}} \\
\beta_{(W / L), j, \text { sepa }}=\frac{(W / L)_{0, \text { stay }}-(W / L)_{0, j, \text { sepa }}}{\overline{(W / L)}},
\end{gathered}
$$

which measure the relative productivity and wage, respectively, of the separated workers. The intercept $\alpha$ indicates the growth rate in the reference age group of the stayers and the coefficients of the included $\mathrm{STAYSH}_{j}$ variables ( $M-1$ age group variables) indicate differences in the growth rate in the age groups $j$ and in the reference group. ${ }^{7}$

In this paper, we are particularly interested in profitability effects. Profitability is measured as follows:

$$
\Pi=1+\frac{O P M}{W(1+a)}=\frac{Y}{W(1+a)}=\frac{Y / L}{(1+a)(W / L)},
$$

where $O P M$ denotes operating margin (i.e., $O P M=Y-W(1+a)$ ), where $a$, the ratio of payroll taxes to wages, is assumed constant over time and across the worker groups.

The growth rate of profitability (15) is therefore the difference between the growth rates of productivity $Y / L$ and wage $W / L$. This relationship can be expressed in a standard manner by using $\log$ differences, i.e.

$$
d \ln \Pi \cong d \ln (Y / L)-d \ln (W / L)
$$

In this study, however, we have used another approximation for the growth rates of productivity and wages in equations (9) and (10). We therefore use an alternative for (16):

$$
\frac{\Delta \Pi}{\bar{\Pi}} \cong \frac{\Delta(Y / L)}{\overline{(Y / L)}}-\frac{\Delta(W / L)}{\overline{(W / L)}}
$$

where $\bar{\Pi}=0.5\left[\Pi_{0}+\Pi_{1}\right]$. 
By inserting (9) and (10) into (17) we obtain an equation for the profitability change

$$
\frac{\Delta \Pi}{\bar{\Pi}}=\alpha+\sum_{j}^{M} \beta_{\Pi, j, h i r e} H R_{j}+\sum_{j}^{M} \beta_{\Pi, j, \text { sepa }} S R_{j}+\sum_{j}^{M-1} \chi_{\Pi, j, \text { stay }} \mathrm{STAYSH}_{j}+\delta^{\prime} \mathbf{Z}+\varepsilon
$$

where, on the basis of (17), the following approximations hold

$$
\begin{aligned}
& \beta_{\Pi, j, \text { hire }} \approx \beta_{(Y / L), j, \text { hire }}-\beta_{(W / L), j, \text { hire }} \\
& \beta_{\Pi, j, \text { sepa }} \approx \beta_{(Y / L), j, \text { sepa }}-\beta_{(W / L), j, \text { sepa }}
\end{aligned}
$$

Since

$$
\beta_{(Y / L), j, \text { hire }}=\frac{(Y / L)_{1, j, \text { hire }}-(Y / L)_{1, \text { stay }}}{\overline{(Y / L)}} \approx \ln \frac{(Y / L)_{1, j, \text { hire }}}{(Y / L)_{1, \text { stay }}}
$$

and

$$
\beta_{(W / L), j, \text { hire }}=\frac{(W / L)_{1, j, \text { hire }}-(W / L)_{1, \text { stay }}}{\overline{(W / L)}} \approx \ln \frac{(W / L)_{1, j, \text { hire }}}{(W / L)_{1, \text { stay }}}
$$

(19) can be developed as follows

$$
\begin{aligned}
& \beta_{\Pi, j, \text { hire }} \approx \ln \frac{(Y / L)_{1, j, \text { hire }}}{(Y / L)_{1, \text { stay }}}-\ln \frac{(W / L)_{1, j, \text { hire }}}{(W / L)_{1, \text { stay }}}=\ln \frac{(Y / W)_{1, j, \text { hire }}}{(Y / W)_{1, \text { stay }}} \\
& \Leftrightarrow \beta_{\Pi, j, \text { hire }} \approx \ln \frac{\Pi_{1, j, \text { hire }}}{\Pi_{1, \text { stay }}}
\end{aligned}
$$

which shows that the parameter of the hiring variable for the worker group $j$ in the profit equation (18) can be interpreted as a measure of the profitability level of the hired group $j$ workers relative to all stayers in period 1.

Analogously, we obtain that

$$
\beta_{\Pi, j, \text { sepa }} \approx \ln \frac{\Pi_{0, j, \text { sepa }}}{\Pi_{0, \text { stay }}}
$$

which provides us a measure of the relative profitability level of the separated group $j$ workers before they leave.

When using equations (9), (10) and (18) for estimation, there are possible sources of bias. First, there can be unobservable firm heterogeneity both in productivity and wage levels, which is correlated with the firms' choice of labor input. In particular, new firms often start with a new work force which only slowly evolves over time (Haltiwanger et al., 1999, 2007). Therefore, 
firm vintage and worker cohorts tend to be tied together, with young workers being employed in firms that have new equipment and a high productivity level. Since we are using growth rates as the dependent variables, this is not an issue of great concern here. That is, if there is an unobserved firm-specific component in the productivity or average wage level, it is eliminated when rates of change are used. Our approach is related to the use of long differences in fixed effects models (e.g. Griliches \& Mairesse, 1998);we define the growth rates and labor flows in twoyear periods. We also control for some observable firm characteristics, included in $Z$.

Second, there is heterogeneity across workers. This would not be an issue if the firms randomly chose new employees from the pool of applicants or randomly picked up those who are laid off. This is not likely to be the case, however, since the firms may hire the best applicants and lay off poor performers. Our hiring and separation flows may therefore be unrepresentative of the corresponding age groups in the whole population. However, the selection bias should affect productivity growth and wage growth in the same way (see Hellerstein \& Neumark, 2004) and therefore be eliminated when we examine their difference, i.e. the productivity-wage gaps which directly relate to our measure of firm performance.

Third, the hiring and separation rates are based on the firms' decisions and are therefore possibly correlated with the error terms. For example, positive productivity shocks may lead to the hiring of new, young workers, which then causes an overestimate of their productivity effect (cf. Olley \& Pakes, 1996; Levinsohn \& Petrin, 2003). On the other hand, one of our main interests is the profitability effect of the separations of older workers. It is not quite obvious why a positive productivity or profitability shock should increase separations of older workers, which would generate a spurious positive correlation between profitability change and the separation of older workers. More probably, a negative profitability shock should increase a company's incentives to encourage its older labor force to early retirement, for instance. As a consequence, our main results are more likely biased in the direction of not showing older workers being overpaid even when they actually may be.

Anyhow, we address this issue in two ways. We identify those older workers who have left the company for the old age pension, which we consider a more exogenous type of separation than the other separations. We also use instrumental variables that take into account exogenous variations in labor supply and demand in the local labor market and the structure of the work force that the firms "inherit” from previous periods. 


\section{Empirical analysis}

\section{1. $\quad$ Data and variables}

The unique identification codes for persons, companies and plants used in the different registers forms the backbone of the Finnish administrative register network and the Finnish statistical system. This provides an excellent opportunity to construct cross-sectionally and dynamically representative data for various research purposes by linking different administrative data sources (see Abowd \& Kramarz, 1999).

The data for this study are drawn from the Finnish Longitudinal Employer-Employee Data (FLEED). The data set merges comprehensive administrative records of all labor force members as well as all employers/enterprises (including information also on their establishments) subject to value added tax (VAT). It can be complemented by a range of additional information from both private and public sources. FLEED currently covers the years 1990-2002 with near-perfect traceability of employers and employees across time. The employment statistics, educational statistics, taxation records, business register, financial statement statistics, manufacturing census as well as various surveys are among the original sources of the FLEED variables.

To define the labor flows and changes in productivity, wage, and profitability, we use 2-year windows. The flows and changes are defined for the 4 periods 1995-97, 1997-99, 1999-2001, and 2001-2003. ${ }^{8}$ The observation unit is a firm. In principle we also have data on establishments, but information on value added, our preferred measure of output, and some other relevant variables, like capital intensity, about establishments are lacking beyond the manufacturing sector. Further, the links between employees and firms are more reliable than those between employees and establishments, especially in multi-unit firms.

Our estimation sample covers the industry sector and service sector. The industry sector consists of mining, manufacturing, public utilities and construction. The service sector comprises retail and wholesale trade, business services and personal services. Real estate and financial intermediation are excluded due to problems in measuring output in a reliable manner. The number of observations in the estimation sample by branches is shown in Appendix Table A.1. 
The dependent variables are defined as follows. Labor productivity growth is measured as a two-year rate of change in value added per employee, average wage is correspondingly a twoyear rate of change in wage sum per employee, and change in profitability is a two-year relative change in value added per labor costs (wages and social security payments). These variables are measured in nominal terms, and price changes (and other industry-specific effects) are controlled by a set industry dummies that are interacted with the period dummies. ${ }^{9}$

The labor flows are based on the comparisons of employees in the firms in two time periods, $t$ and $t-2$. The flow rates are calculated separately for three age groups, “young” (- 30 years), “middle-aged” (31-50 years), and “old” (51 - years). We use fairly broad age groups to ensure that we have enough employees in the groups when hiring and separation are disaggregated by age. In each period age is based on the situation at the end year. For example, those who were 28 years old in $t-2$, are 30 years old in $t$ and hence included among the "young”. Those who were 30 already in year $t-2$, are 32 in $t$, and hence included in the middle group. The age group classification is thus based on year $t$ age, and not on the age at which the employees were last observed in the firm.

The hiring rate $H R_{j i t}$ for age group $j$ is the number of new employees in firm $i$ in the age group (those in the firm in $t$, but not in $t$-2) divided by the number of all employees of the firm in $t$. The separation rate $S R_{j i t}$ is correspondingly the number of exited employees of firm $i$ in age group $j$ (those in the firm in $t$-2, but no longer in $t$ ), divided by the number of all employees in the firm in $t-2$. The share of stayers, $S T A Y S H_{j i t}$, is the number of staying employees of firm $i$ in age group $j$ (those in the firm both in $t$ and $t-2$ ), divided by all stayers of the firm in $t-2$. The sum of these stayer shares is therefore one, so one of the groups is left out of the estimation.

As controls we use the various characteristics of the plants. We control for the log of capital per employee, which is entered in difference form to be consistent with the form of the dependent variables. The initial levels (in $t-2$ ) of log of value added per worker and log of average wage account for catching-up effect. Finally, we have a set of dummy variables. These include interacted industry and period dummies (46 industries) to account for the effects of idiosyncratic industry shocks, and likewise a set of dummies as controls for regional effects (20 regions). 
Since the labor flows may be endogenous, we use a number of instrumental variables for them. In the construction of the instruments we have used the rich employer-employee data, which make it possible to combine data on individuals and firms to measures of local labor market conditions. Hiring of new employees can be instrumented with variables that account for exogenous regional shifts in labor supply in the three age groups. Our first instrument is the number of individuals who have graduated from institutions of secondary or higher level education per working age population in the area (or areas) where the firm is situated during the years $t-2$ and $t-3 .{ }^{10}$ The area is defined as the municipality where the firm is located and all adjoining municipalities. ${ }^{11}$ For the firms that operate in many areas, we use a weighted average of the areas in question. The other instruments for hiring are the age-group specific separation rates of employees in the business sector in the area where the firm is located, calculated by using establishment level data. These regional separation rates between periods $t-4$ and $t-2$ are used as instruments for hiring of firms operating in the area between periods $t-2$ and $t$. All of these instruments describe exogenous shifts in the availability of new employees of different ages.

To instrument separations we use variables that account for regional shifts in labor demand that may lead to job-to-job switches. We use as instruments the hiring rates of the three age groups in the area where the firm operates. These are calculated in the same way as the separation rates. The regional hiring rates by age groups between periods $t-4$ and $t-2$ are used as instruments for separations in firms operating in the area between periods $t-2$ and $t$. As a robustness check we estimate the model by dropping the continuing employee age group shares and use them instead as additional instruments. They describe the potential out of which the separations happen. In addition, we use the shares of homeowners among each firm's employees in the age groups as instruments for separation. One can argue that home ownership creates adjustment costs for job switching and therefore should work as an instrument for the separation rates.

Before conducting the econometric analysis we leave out some potentially erroneous observations that may distort our results. First, we remove those observations where the number of linked employees differs more than $10 \%$ from the number of employees in the company data. This indicates that the linking of the individual and firm data is incomplete. Second, we remove some potentially influential outliers that we detecte by using the method proposed by Hadi (1992; 1994). The method is useful for detecting multiple outliers in multivariate data. 
Identification of outliers is made on the basis of three variables: 1) the growth rate of average monthly earnings calculated from the data on individuals (the Employment Statistics), 2) the growth rate of average wage calculated from the company data, and 3) the productivity growth rate. The first two variables should be highly correlated with each other because they are essentially gauging the same thing, but may sometimes differ due to possible inaccuracies in the links between employees and their employers, for instance. Wage growth is usually correlated with productivity growth, but sometimes they may be very different because of measurement errors in output and/or labor input. The identified outliers (418 out of 19452 firm-period observations) are removed from all estimations except the median regression estimation (see Appendix Table A.2). We also restrict the sample to firms that employ at least 10 employees and leave out the firms with over 10000 employees; 8 observations are dropped from the sample due to the upper limit.

\subsection{Estimation results}

Table 1 gives some descriptive summary statistics of our basic sample that is used in the regression analysis below. Because some observations cannot be used in the analysis due to missing values of the explanatory variables, we are finally left with 18848 observations. The average number of linked employees per company is 85.2, which is close to the average number of employees in these firms according to company data (85.9 employees measured in fulltime equivalents). In other words, our regressions are based on 1.62 million individual-period observations. Because we have four periods, our sample covers about 405000 individuals per period. This figure includes those individuals who are employed by a company in our sample either in the initial or end year or both. This is roughly one third of the total employment in the non-farm business sector. ${ }^{12}$

The average nominal productivity growth rate in the 2-year periods is $4.1 \%$. Average wage growth rate, calculated from company data, is $6.7 \%$. This is reasonably close to the average growth of monthly earnings of the linked employees, 6.9\%, obtained from the register data on individuals (Employment Statistics). The average level of monthly earnings is $€ 2130$. The average hiring rate, which is the sum of the hiring rates of the three age groups, is $28.6 \%$ and the average separation rate, sum of the separation rates of the three age groups, is $24.5 \%{ }^{13}$ Young employees account for $17.2 \%$ of the staying employees and the old workers account for $20.9 \%$. 
Table 1. Descriptive statistics of the estimation sample

Variable

Average employment (CD)

Average employment (ES)

Labor productivity growth rate

Wage growth rate (CD)

18848

Average $\mathrm{p} 1$

Median p99

$\begin{array}{lllll}18848 & 85.2 & 11.0 & 25.5 & 1029.0\end{array}$

$\begin{array}{lllll}18848 & 0.041 & -0.732 & 0.044 & 0.763\end{array}$

Wage growth rate (ES)

18848

0.067

$-0.433$

0.068

0.556

Profitability growth rate

18848

0.069

$-0.181$

0.068

0.326

Monthly earnings (ES), in euros

18848

$-0.026$

$-0.713$

$-0.021$

0.623

Hiring of -30 years

18848

2130

1108

2025

4226

Hiring of 31-50 years

0.143

0.000

0.118

0.545

18848

0.122

0.000

0.100

0.448

Hiring of 51- years

18848

0.021

0.000

0.000

0.167

Separation of -28 years

18848

0.086

0.000

0.058

0.484

Separation of -28 years, unemployment.

18848

$0.010 \quad 0.000$

0.000

0.105

Separation of -28 years, other

0.076

0.000

0.050

0.444

Separation of 29-48 years

18848

0.117

0.000

0.083

0.563

Separation of 29-48 years, unemployment

18848

0.022

0.000

0.000

0.200

Separation of 29-48 years, other

18848

0.096

0.000

0.068

0.474

18848

0.042

0.000

0.023

0.267

Separation of 49 - years, retirement

18848

$0.012 \quad 0.000$

0.000

0.111

Separation of 49- years, unemployment

18848

$0.014 \quad 0.000$

0.000

0.152

Separation of 49- years, other

Share of staying -30 years

18848

$0.015 \quad 0.000$

0.000

0.154

Share of staying 31-50 years

Share of staying 51- years

18848

$0.172 \quad 0.000$

0.135

0.686

18848

0.619

0.188

0.626

1.000

18848

0.209

0.000

0.200

0.600

15979

0.574

0.143

0.510

1.000

Share of home owners among 31-50 years

18765

0.719

0.250

0.741

1.000

Share of home owners among 51- years

16710

0.849

0.333

$0.886 \quad 1.000$

Note: CD and ES refer to Company Data and Employment Statistics information, respectively.

Table 2 reports the basic estimates. All of the estimation results reported below are based on weighted estimation, with firm employment used as the weight. The entries in the third column are from a separate estimation for profitability change, but they are roughly equal to the differences of the entries for productivity and wage change in the first two columns. The results show that hiring of young employees lowers the productivity level, presumably because of their lack of general skills. However, they also have lower wages, so that the profitability effect is close to zero. Hiring the mid-aged has a modest negative effect on productivity and a modest positive wage effect, but neither is statistically significant. However, there is a statistically significantly negative net effect on profitability. The hired old workers have considerably lower wage level than the average staying worker in year $t$ and therefore these recruitments are not a burden to firms.

On the separation side, exiting young employees have a negative impact both on productivity and wage. One interpretation of this result is that it is the best performers who have already 
gained some experience in the firm who are leaving. Our point estimates suggest that young leavers are underpaid, but because of a relatively large standard error the profitability effect does not differ from zero in a statistically significant way. However, when the profitability gap of young leavers is compared to that of the oldest leavers, the difference of $23.5 \%$ (17.2\%-(-6.3\%)) is significant economically and statistically. Separation of the older employees has a fairly high positive productivity effect and a smaller wage effect. These estimates indicate that the separating older employees have a lower productivity level than the continuing employees, but they are also paid somewhat less on average. The net effect is thus an increase in profitability. These results seem to support the deferred pay argument or the final salary pension that gives further incentives to bargain for wage profiles that give a high pay at the end of the career. ${ }^{14}$

Table 2. Productivity, wage and profit equations in the business sector

\begin{tabular}{|c|c|c|c|}
\hline & $\begin{array}{l}\text { Productivity } \\
\text { (1) }\end{array}$ & $\begin{array}{l}\text { Wages } \\
\text { (2) }\end{array}$ & $\begin{array}{l}\text { Profits } \\
\text { (3) }\end{array}$ \\
\hline Hired -30 yrs. & $\begin{array}{l}-0.133^{* * *} \\
(0.047)\end{array}$ & $\begin{array}{l}-0.163^{* * *} \\
(0.023)\end{array}$ & $\begin{array}{r}0.028 \\
(0.040)\end{array}$ \\
\hline Hired 31-50 yrs. & $\begin{array}{l}-0.043 \\
(0.043)\end{array}$ & $\begin{array}{r}0.034 \\
(0.022)\end{array}$ & $\begin{array}{l}-0.078^{* *} \\
(0.038)\end{array}$ \\
\hline Hired 51-yrs. & $\begin{array}{l}-0.082 \\
(0.168)\end{array}$ & $\begin{array}{l}-0.148^{* *} \\
(0.064)\end{array}$ & $\begin{array}{r}0.060 \\
(0.141)\end{array}$ \\
\hline Separated -28 yrs. & $\begin{array}{l}-0.150 * * * \\
(0.057)\end{array}$ & $\begin{array}{l}-0.084^{* * *} \\
(0.029)\end{array}$ & $\begin{array}{l}-0.063 \\
(0.064)\end{array}$ \\
\hline Separated 29-48 yrs. & $\begin{array}{l}-0.036 \\
(0.026)\end{array}$ & $\begin{array}{r}0.012 \\
(0.009)\end{array}$ & $\begin{array}{l}-0.048^{*} \\
(0.028)\end{array}$ \\
\hline Separated 49-yrs. & $\begin{array}{c}0.237^{* * *} \\
(0.083)\end{array}$ & $\begin{array}{c}0.066^{* * *} \\
(0.023)\end{array}$ & $\begin{array}{c}0.172^{*} \\
(0.088)\end{array}$ \\
\hline Stayers 31-50 yrs. & $\begin{array}{l}-0.005 \\
(0.044)\end{array}$ & $\begin{array}{r}0.003 \\
(0.017)\end{array}$ & $\begin{array}{r}-0.010 \\
(0.041)\end{array}$ \\
\hline Stayers 51- yrs. & $\begin{array}{r}-0.068 \\
(0.046)\end{array}$ & $\begin{array}{l}-0.066^{* * *} \\
(0.020)\end{array}$ & $\begin{array}{r}-0.006 \\
(0.041)\end{array}$ \\
\hline Observations & 18848 & 18848 & 18848 \\
\hline R-squared & $\odot .247$ & $\odot .222$ & 0.271 \\
\hline
\end{tabular}

Note: Other variables include the initial wage and productivity levels (in logs), log-change in capital per labor, regional dummies and interactions of industry and period dummies. Employment weighted estimation. Firms with at least 10 and at most 10000 employees included.

As a robustness check of the results we have also estimated the model of Table 2 by using median regression (Appendix Table A.2), but our main conclusions remain intact. To investi- 
gate whether the results hold for different types of sub-sectors within the whole business sector, we estimate the models separately for the industry sector and the service sector. Table 3 shows that there are some notable differences in the results between these sectors. We find that the $\mathrm{R}^{2}$ measures of the productivity and profitability equations are substantially higher in the industry sector than in the service sector. This may reflect a greater importance of idiosyncratic factors or measurement problems regarding productivity and profitability in service industries. In the wage equation $\mathrm{R}^{2}$ is similar in both sectors.

More interestingly, separation of older workers is particularly profitable in the industry sector. This implies overpayment of older workers, compared to their productivity. This is even more pronounced in comparison to the negative profitability effect of separations of medium aged workers. In addition, in the industry sector we find evidence that the dynamic effects of the older workers are negative, since continuing older workers have a negative impact on the productivity and profitability growth rates. In the service sector the results are different in several respects. All the labor flows are profit neutral to firms except the hiring of medium aged workers, which affects profits negatively. Clearly, we cannot find a "Wall-Mart effect" in services, but in the industry sector there is an "Ericsson effect".

The separations of the oldest age group may be driven by very different influences. Some of these employees are retiring. Some are laid off and may face periods of unemployment. Some are still looking for new jobs and quit to move to other firms. Finally, some withdraw from the labor market. To investigate whether there are significant differences in the impacts of different types of separations on firm performance, we have disaggregated the separation rate of the age group over 50 years into three flow rates. These are separation rate to pension (old age pension or disability pension), unemployment (including unemployment pension), and other (job-to-job moves and withdrawal from the labor market). For the sake of comparison, we have divided separations of the other age groups by destination into unemployment and other. There are very few in these age groups who end up into retirement; they have been included in the category "other". The estimation results with this disaggregation are shown in Table 4.

Now the outflow of older workers into retirement and unemployment is found to have a statistically and economically significant positive impact on productivity indicating that these worker groups had lower than the average productivity level before they left. The results for 
Table 3. Productivity, wage and profit equations by sectors

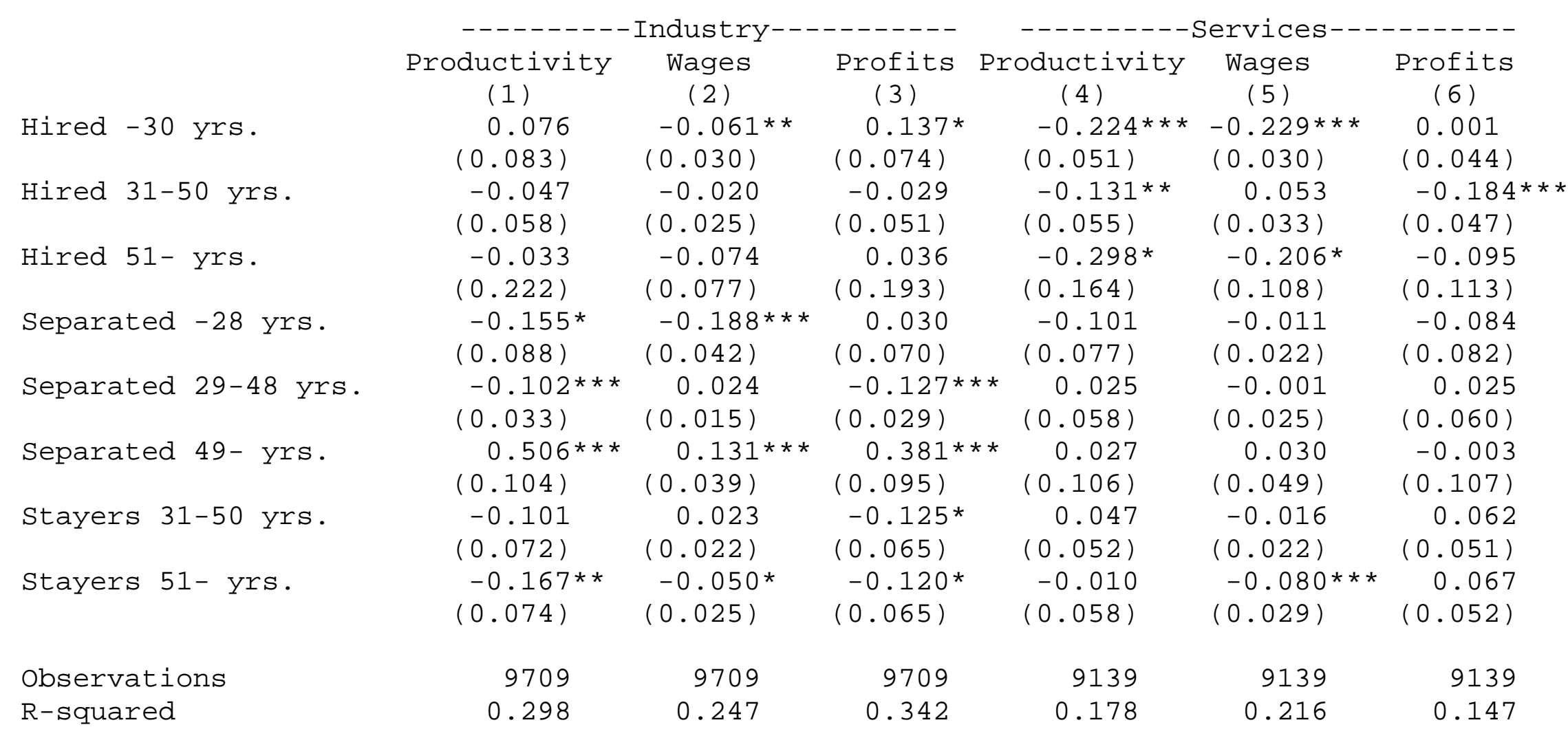

* $p<0.1, * * p<0.05, * * * p<0.01$

Note: Other variables include the initial wage and productivity levels (in logs), log-change in capital per labor, regional dummies and interactions of industry and period dummies. Employment weighted estimation. Firms with at least 10 and at most 10000 employees included. 
Table 4. Productivity, wage and profit equations with disaggregation by destination in the business sector

\section{Productivity Wages Profits}

(1) (2) (3)

\begin{tabular}{|c|c|c|c|c|}
\hline Hired & -30 yrs. & $\begin{array}{l}-0.131^{* * *} \\
(0.046)\end{array}$ & $\begin{array}{l}-0.173 * * * \\
(0.023)\end{array}$ & $\begin{array}{l}0.040 \\
(0.040)\end{array}$ \\
\hline Hired & $31-50$ yrs. & $\begin{array}{l}-0.038 \\
(0.042)\end{array}$ & $\begin{array}{r}0.036^{*} \\
(0.021)\end{array}$ & $\begin{array}{l}-0.075^{* *} \\
(0.037)\end{array}$ \\
\hline Hired & $51-$ yrs. & $\begin{array}{l}-0.072 \\
(0.168)\end{array}$ & $\begin{array}{l}-0.145^{*} \\
(0.064)\end{array}$ & $\begin{array}{c}0.067 \\
(0.142)\end{array}$ \\
\hline Sep. - & -28 yrs., other & $\begin{array}{l}-\odot .135^{\star *} \\
(\odot .066)\end{array}$ & $\begin{array}{l}-0.045^{*} \\
(0.026)\end{array}$ & $\begin{array}{l}-\odot .086 \\
(\odot .072)\end{array}$ \\
\hline Sep. - & -28 yrs., unemp. & $\begin{array}{l}-0.253 \\
(\odot .204)\end{array}$ & $\begin{array}{l}-0.439 * * * \\
(0.108)\end{array}$ & $\begin{array}{c}0.177 \\
(0.169)\end{array}$ \\
\hline Sep. 2 & 29-48 yrs., other & $\begin{array}{r}-0.013 \\
(0.029)\end{array}$ & $\begin{array}{l}\odot .019 * * \\
(\odot .0 \odot 9)\end{array}$ & $\begin{array}{l}-0.032 \\
(0.033)\end{array}$ \\
\hline Sep. 2 & 29-48 y., unemp. & $\begin{array}{r}-0.076 \\
(0.118)\end{array}$ & $\begin{array}{l}-0.117^{* *} \\
(0.049)\end{array}$ & $\begin{array}{c}0.045 \\
(\odot .099)\end{array}$ \\
\hline Sep. 4 & 49-yrs., other & $\begin{array}{c}0.126 \\
(0.099)\end{array}$ & $\begin{array}{c}0.036 \\
(0.028)\end{array}$ & $\begin{array}{c}0.089 \\
(0.117)\end{array}$ \\
\hline Sep. 4 & 49-yrs., unemp. & $\begin{array}{l}0.434^{* * *} \\
(0.136)\end{array}$ & $\begin{array}{r}0.103^{*} \\
(0.062)\end{array}$ & $\begin{array}{l}0.337^{* * *} \\
(0.116)\end{array}$ \\
\hline Sep. 4 & 49-yrs., pension & $\begin{array}{l}0.363^{* *} \\
(0.180)\end{array}$ & $\begin{array}{c}0.085 \\
(0.069)\end{array}$ & $\begin{array}{l}\odot .280^{*} \\
(0.170)\end{array}$ \\
\hline Stayer & rs 31-50 yrs. & $\begin{array}{l}-\odot .009 \\
(0.044)\end{array}$ & $\begin{array}{c}0.003 \\
(0.016)\end{array}$ & $\begin{array}{l}-0.014 \\
(0.041)\end{array}$ \\
\hline Stayer & rs 51-yrs. & $\begin{array}{l}-0.077^{*} \\
(0.046)\end{array}$ & $\begin{array}{l}-0.070 * * * \\
(0.020)\end{array}$ & $\begin{array}{l}-0.010 \\
(0.041)\end{array}$ \\
\hline Observ & vations & 18848 & 18848 & 18848 \\
\hline $\mathrm{R}$-squa & ared & 0.247 & 0.225 & 0.272 \\
\hline
\end{tabular}

Note: Other variables include the initial wage and productivity levels (in logs), log-change in capital per labor, regional dummies and interactions of industry and period dummies. Employment weighted estimation. Firms with at least 10 and at most 10000 employees included.

wages (the second column) show that the wage level of these workers did not differ significantly from the average level. In other words, our results indicate that these worker groups had been paid more than their productivity and their separations have been thus profitable to firms. This can also be seen in the positive coefficients of the third column, the profit equation. The productivity-wage gap is quite substantial, about 30\%. On the other hand, the results of Table 4 do not provide evidence that those older workers that have left the firm for some other destination, e.g. employment in another firm, had been overpaid. These workers account for roughly one third of the total separations of the older workers. So, a substantial proportion of the older workers are not found to be 
overpaid in our analysis. Interestingly, we do not find statistical evidence that those young or middle aged workers who separated into unemployment had been overpaid.

Our interpretation of the results is that especially the outflows to unemployment reflect the firms' choices whereas especially the route to old-age pension is a more exogenous event to the firm. It is worth noting that the Finnish pension and unemployment insurance systems have an exit route called "unemployment pension pipeline”, which allows unemployed to withdraw from the labor market at a relatively early stage by successively transferring to unemployment compensation, unemployment pension and finally to normal pension. It has actually been relatively common for the firms to use this system for downsizing their labor force, which can be seen as an increase in the unemployment risk at an age where the "pipeline" starts. ${ }^{15}$ It can also be argued that the use of the unemployment pension has in many cases been in the mutual interest of the firms and their employees (Hakola \& Uusitalo, 2005). Our results are quite consistent with the existence of this policy that makes it easy for firms to concentrate labor shedding to the older employees.

The use of temporary workers also makes it easy and cheap to downsize the labor force when necessary. Unfortunately, our data do not allow us to distinguish between temporary and permanent employees. We can still speculate on the likely impacts, since the temporary employees are usually young. One can argue that concentration of layoffs to temporary employees is one reason why the average age of employees in Finland rose during the depression in the early 1990s (see Ilmakunnas et al., 2004). Also Table 1 above shows that the flow rate to unemployment has been highest among the young. However, our estimation results do not give support to the view that this kind of downsizing would have been profitability-enhancing.

In table 5 we show the results with disaggregation of separations by destination, estimated separately for the industry and service sectors. A similar picture emerges as before: we find evidence that the older workers are overpaid in the industry sector, but not in the service sector. In services the labor flows are generally profit neutral, except for hiring of the medium aged workers, which has a negative effect. According to the results for the industry sector, those older worker who leave their employer and end up in unemployment or old age pension have a very low productivity level and their exit is therefore very profitable for the firms. Further, having a large share of staying older workers has a negative effect on the productivity and profitability growth rates. 
Table 5. Productivity, wage and profit equations with disaggregation by destination and by sectors

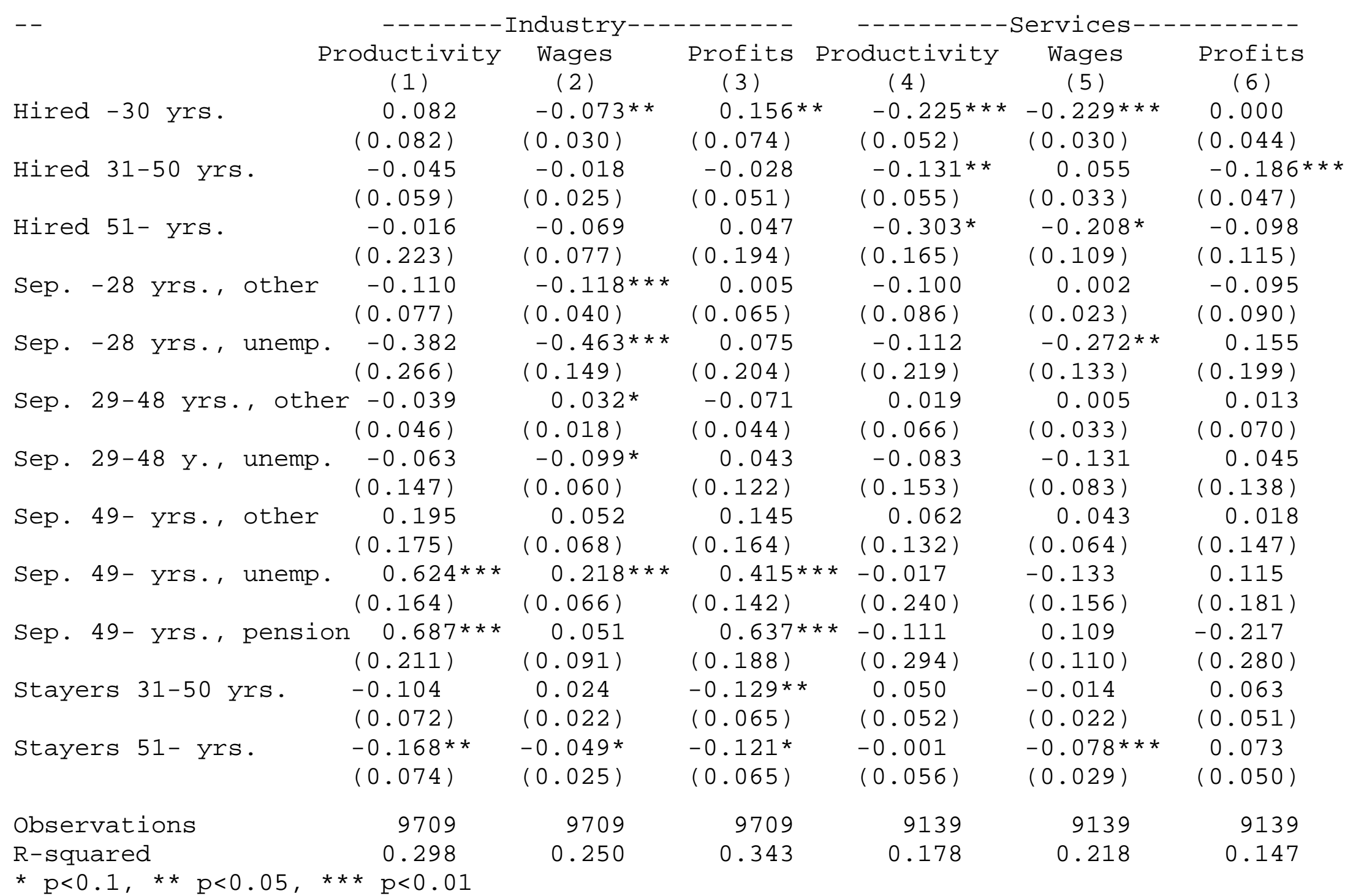

Note: Other variables include the initial wage and productivity levels (in logs), log-change in capital per labor, regional dummies and interactions of industry and period dummies. Employment weighted estimation. Firms with at least 10 and at most 10000 employees included. 
Table 6. Profit equation by sectors and by ICT/non-ICT division, narrow ICT definition

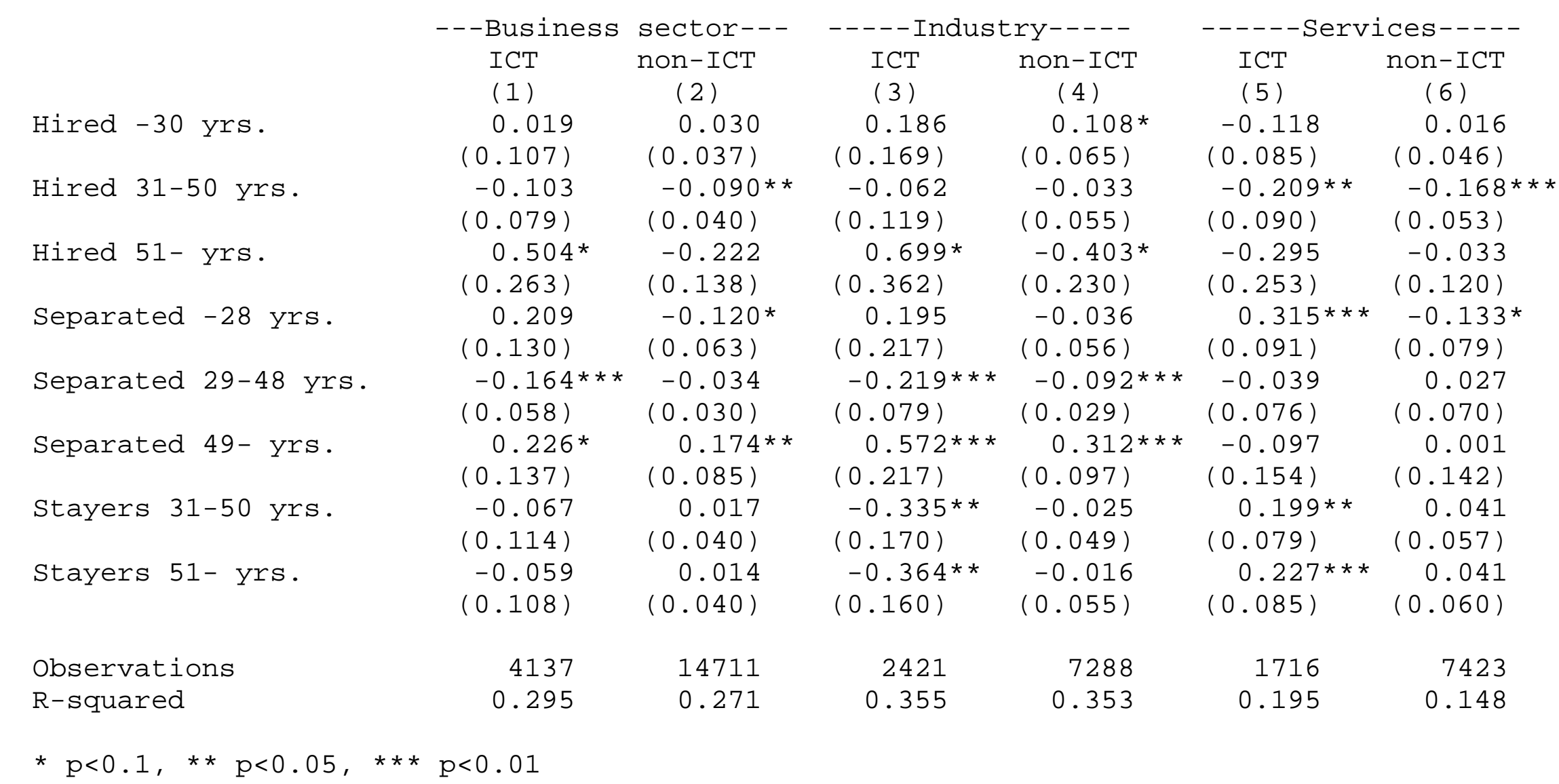

Note: Other variables include the initial wage and productivity levels (in logs), log-change in capital per labor, regional dummies and interactions of industry and period dummies. Employment weighted estimation. Firms with at least 10 and at most 10000 employees included. 
In order to examine more carefully what drives our findings of the negative productivity and profitability effects especially in the industry sector we have sliced our data a little bit more. First, we have classified the companies into ICT and non-ICT groups on the basis of 2- or 3digit industries. Our starting point is the widely used classification proposed by van Ark et al. (2003). In their classification the ICT industries of the business sector consist of a broad variety of different industries such as “Apparel” (ISIC 18), "Printing and Publishing” (ISIC 22), “Machinery” (ISIC 29), “Office and computer equipment” (ISIC 30), “Electrical machinery” (ISIC 31), "Radio, TV and communication equipment” (ISIC 32), "Instruments” (ISIC 33), “Transport equipment” (ISIC 35), “Miscellaneous manufacturing” (ISIC 36-37), "Wholesale” (ISIC 51), “Retail” (ISIC 52), “Telecommunications” (ISIC 64), "Renting of machinery” (ISIC 71), “Computer services” (ISIC 72), “R\&D” (ISIC 73), and “Professional services” (ISIC 741-743). ${ }^{16}$ The results obtained by using this broad definition of ICT are reported in Appendix Table A.5. We have, however, chosen to use a somewhat narrower definition. ${ }^{17}$ More specifically, we have excluded industries 18, 35, 36-37, 51, and 52 from the group of ICT industries.

Table 6 shows the results of the profitability change equation for the ICT and non-ICT industries. (Appendix Tables A.3 and A.4 show the results of productivity and wage equations separately.) Columns (1) and (2) present the estimates for the whole non-farm business sector. The coefficients for the separations of the older workers are quite similar for the ICT and nonICT parts of the business sector. As for the medium aged workers, there is a significant negative separation effect in the ICT industries and a significant negative hiring effect in the nonICT industries. That is, these workers in the ICT sector have high productivity and a wage level that does not exceed the average pay. In contrast, in the non-ICT sector their pay exceeds productivity.

Columns (3) and (4) show the corresponding results for the ICT and non-ICT parts of the industry sector, respectively. It should be noted that all the ICT industries of the industry sector belong to manufacturing. The results of column (3) thus provide evidence that older workers may be a burden to firms particularly in the manufacturing ICT industries. The separation of older workers has a strong positive effect and the share of staying older workers a strong negative effect on the profitability growth rate. This is mainly due to a negative NelsonPhelps effect, i.e. the older workers affect productivity growth negatively (Table A3). However, in contrast to these results, hiring of older workers has positive profitability and produc- 
tivity effects. It seems that the firms are able to pick up highly productive employees without having to pay them more than for average existing workers. In the non-ICT part of the industry sector, staying older workers do not have a significant effect on profitability growth, but the separation of older workers is profitable and hiring unprofitable for the firms. As to the other age groups, the separation of medium aged workers has a strong negative profitability effect in the ICT industries, but also staying mid-aged have a negative influence.

The results for the service sector are quite different. In the ICT industries of the service sector, the older workers have a positive effect on profitability growth. This comes mainly from a positive productivity effect (see Appendix Table A.3). Further, the separations of the young workers have a positive effect on profitability in the ICT industries but a negative effect in the non-ICT industries.

A comparison of the results obtained with the narrow definition (i.e. Table 6) and with a broad definition of ICT (Appendix Table A.5) suggests that our preferred classification makes a sharper, and probably more plausible, distinction between the two kinds of industries, especially in the industry sector. Analysis made with the narrow definition provides strong evidence supporting the view that older workers constitute a burden to firms because skill obsolesce lowers their relative productivity and, in addition, weakens their ability to adopt or innovate new technologies. However, when the firms of the whole business sector are classified on the basis of the broad ICT definition, the separations of old workers appear particularly profitable in the non-ICT industries. The results for the service sector seem somewhat unexpected with both ITC definitions.

One might suspect that our results are driven by some kind of downsizing effect, i.e. that firms aim to improve their profitability by reducing their work force. The relationship between labor flows and profitability would in this case be dominated by separations in downsizing firms. It should be noted, however, that while our explanatory variables include all hiring and separation flows, we have implicitly controlled the employment growth (or decline) effect. In any case, for inspecting the downsizing hypothesis more carefully we have estimated the profitability equation by dividing the firms into two separate groups: the declining firms where employment has decreased and the expanding ones where employment has increased. These results are shown in Appendix Table A.6. Generally, we find that the results for the declining and expanding firms are very similar to each other both in the whole business sector as well as in the industry and service sectors when considered separately. 
In the analysis above the fixed firm effects were eliminated by using two-year differences. However, our main findings would be biased if, for instance, the separation of older workers was a consequence of a profitability shock to the firm. So, due to the potential endogeneity of the hiring and separation flows we have estimated the models using the instrumental variables discussed in Section 4 above. Since the shares of the stayers can be considered as more exogenous than the hiring and separation rates, we have not instrumented them. We concentrate on the profitability change equation. The instrumental variables estimates are reported in Table 7. In column (1) we present the results for the whole business sector, in column (2) for the industry sector and in (3) for the service sector.

Table 7. Instrumental variables estimates of the profit equation

\begin{tabular}{|c|c|c|c|}
\hline & $\begin{array}{c}\text { Business sector } \\
\text { (1) }\end{array}$ & $\begin{array}{l}\text { Industry } \\
\text { (2) }\end{array}$ & $\begin{array}{l}\text { Services } \\
\text { (3) }\end{array}$ \\
\hline \multirow[t]{2}{*}{ Hired -30 yrs. } & 0.325 & 0.026 & -0.570 \\
\hline & $(0.634)$ & $(1.454)$ & $(0.942)$ \\
\hline Hired 31-50 yrs. & $\begin{array}{r}-0.010 \\
(0.836)\end{array}$ & $\begin{array}{l}-0.597 \\
(1.271)\end{array}$ & $\begin{array}{l}-0.344 \\
(0.994)\end{array}$ \\
\hline Hired 51-yrs. & $\begin{array}{l}-6.402^{*} \\
(3.854)\end{array}$ & $\begin{array}{l}-4.221 \\
(4.786)\end{array}$ & $\begin{array}{r}0.962 \\
(4.904)\end{array}$ \\
\hline Separated -28 yrs. & $\begin{array}{r}0.019 \\
(0.818)\end{array}$ & $\begin{array}{l}-0.044 \\
(1.274)\end{array}$ & $\begin{array}{l}-1.082^{*} \\
(0.639)\end{array}$ \\
\hline Separated 29-48 yrs. & $\begin{array}{l}-0.809 \\
(0.592)\end{array}$ & $\begin{array}{l}-0.753 \\
(0.602)\end{array}$ & $\begin{array}{r}1.646 \\
(1.570)\end{array}$ \\
\hline Separated 49-yrs. & $\begin{array}{c}2.213^{* *} \\
(1.097)\end{array}$ & $\begin{array}{l}2.051 * * \\
(0.970)\end{array}$ & $\begin{array}{l}-2.161 \\
(2.476)\end{array}$ \\
\hline Stayers $31-50$ yrs. & $\begin{array}{r}0.114 \\
(0.289)\end{array}$ & $\begin{array}{l}-0.188 \\
(0.313)\end{array}$ & $\begin{array}{l}-0.532 \\
(0.561)\end{array}$ \\
\hline Stayers 51- yrs. & $\begin{array}{r}0.021 \\
(0.260)\end{array}$ & $\begin{array}{r}-0.394 \\
(0.273)\end{array}$ & $\begin{array}{l}-0.272 \\
(0.449)\end{array}$ \\
\hline Observations & 16389 & 8970 & 7419 \\
\hline Overident. test (a) & 0.729 & 0.528 & 0.179 \\
\hline Relevance test (b) & 0.005 & 0.023 & 0.369 \\
\hline $\begin{array}{l}\text { * } p<0.1, * * p<0.05, \\
\text { (a) Hansen-Sargan J } \\
\text { (b) Anderson canonic }\end{array}$ & $\begin{array}{l}* * * p<\odot .01 \\
\text { statistics, } p- \\
\text { al correlation }\end{array}$ & $\begin{array}{l}\text { alue } \\
\text { LR s }\end{array}$ & \\
\hline
\end{tabular}

Note: Hiring and separation variables instrumented. Exogenous variables: the initial levels of productivity and wage in logs, 2-digit industry dummies. Instruments: Regional worker inflow and outflow variables by age group, share of home-owners (for more details, see the text). 
The coefficients are much larger in absolute value than in the OLS estimations, but they are fairly imprecisely estimated. Although the instrumental variables estimation renders most of the flow variables insignificant, our strongest result in the OLS estimations still gets support. The separation of old workers has been profitable for the firms in the whole business sector and in the industry sector. However, we now find evidence that also the hiring of older workers is unprofitable. The overidentification test with the Hansen-Sargan J test statistic shows that the null hypothesis of no correlation between our instruments and the error terms can be accepted. Hence our instruments are valid. The instrument relevance test with Anderson's canonical correlations test shows that the hypothesis of no correlation between our instruments and the potentially endogenous flows can be rejected for the business sector and industry sector. However, for the service sector there is indication that the instruments are weak. However, as usual with the IV estimations the results should be interpreted with caution.

\section{Conclusions}

We have proposed a new way of estimating the performance effects of age using flows of labor to and from firms. The results support the argument that at the end of the working career wage exceeds productivity. Older workers appear to be particularly costly to firms in the manufacturing ICT industries. Further, the results indicate that in these cases older workers have a negative effect on profitability (and productivity) growth, on top of lowering the current profitability (and productivity) level of the firm. These findings may be explained by rigidities in the wage formation which drive a wedge between the wage and productivity levels of older workers when rapid technological change makes skills obsolete at a rate that exceeds the rate of learning-by-doing. Such rigidities may derive from deferred compensation, employment protection that is focused more heavily on older workers, or insider power of the older workers in wage bargaining.

There are also differences between separations of the oldest employees to various destinations. It should be noted that our estimates gauge the total effects of outflows of the oldest workers on productivity. Besides a direct productivity effect (i.e. a worker's efficiency in her own task), the estimates of this kind of analysis may arguably also capture various indirect effects that come into being through the diffusion of knowledge between different worker 
groups within a firm. Important as the diffusion of the tacit knowledge of older worker to the younger ones may be in many circumstances to the employer, our results, however, suggest that generally this effect does not outweigh possible shortages in productivity or ability to adopt new and more productive techniques.

While the results are consistent with the idea of deferred compensation, the institutional setting has obviously also contributed to the results. Firms have incentives to downsize by laying off the oldest employees. On the other hand, the pension system has given incentives for wage profiles that peak at the end of the career. Our results support the view that firms have followed these incentives created by the institutional setting for improving their performance.

There are changes in the labor market, however, that will in the future increase incentives for keeping the aging labor force at work. Pension reforms increase the mandatory retirement ages or extend employees' rights to stay at work. There is also reduced availability of labor because of smaller age cohorts. These developments create pressures for firms to keep their older employees and to use new means for improving their performance, like changes in work organization and rotation of tasks. There may be shifts away from final salary pensions to systems where the benefits are more closely tied to contributions over the working career. The new environment with longer, less fixed retirement age, and fewer incentives for bargaining a back-loaded wage may give rise to flatter age-wage profiles in the future. ${ }^{18}$ 


\section{References}

AARP. (2005). The Business Case for Workers Age 50+. Washington DC: AARP.

Abowd, J. M. and Kramarz, F. (1999). The Analysis of Labor Markets Using Matched EmployerEmployee Data. In O. Ashenfelter \& D. Card (Eds.), Handbook of Labor Economics. Volume $3 B$ (pp. 2629-2710). Amsterdam; New York and Oxford: Elsevier Science, North-Holland.

Aghion, P. and Howitt, P. (1996). The Observational Implications of Schumpeterian Growth Theory. Empirical Economics, 21(1), 13.

Aubert, P., Caroli, E. and Roger, M. (2006). New Technologies, Organisations and Age: Firm-Level Evidence. The Economic Journal, 116(February), 73-93.

Aubert, P. and Crépon, B. (2003). La Productivité des Salariés Âgés: Une Tentative d’Estimation. Économie Et Statistique, $n^{\circ} 368,95-119$.

Bingley, P. and Westergaard-Nielsen, N. (2004). Personnel Policy and Profit. Journal of Business Research, 57, 557-563.

Bishop, J. H. (1990). Job Performance, Turnover, and Wage Growth. Journal of Labor Economics, 8(3), 363-386.

Blakemore, A. E. and Hoffman, D. L. (1989). Seniority Rules and Productivity: An Empirical Test. Economica, 56(223), 359-371.

Brown, C., Haltiwanger, J. and Lane, J. (2006). Economic Turbulence: Is a Volatile Economy Good for America? Chicago: University of Chicago Press.

Dalton, D. R., Todor, W. D. and Krackhardt, D. M. (1982). Turnover Overstated: The Functional Taxonomy. Academy of Management Review, 7(1), 117-123.

Daniel, K. and Heywood, J. S. (2007). The Determinants of Hiring Older Workers: UK Evidence. Labour Economics, 14(1), 35-51.

Daveri, F. (2004). Delayed IT Usage: Is It Really the Drag on Europe's Productivity. CESifo Economic Studies, 50(3), 397-421.

Daveri, F. and Maliranta, M. (2007). Age, Seniority and Labour Costs:Lessons from Finnish IT Revolution. Economic Policy, 22(49), 117-175.

Diewert, W. E. and Fox, K. A. (2005). On Measuring the Contribution of Entering and Exiting Firms to Aggregate Productivity Growth. Department of Economics, University of British Columbia, Discussion Paper No. 05-02. Vancouver.

Foster, L., Haltiwanger, J. and Krizan, C. J. (2001). Aggregate Productivity Growth: Lessons from Microeconomic Evidence. In C. R. Hulten, E. R. Dean \& M. J. Harper (Eds.), New Developments in Productivity Analysis (pp. 303-363). Chicago and London: University of Chicago Press.

Griliches, Z. and Mairesse, J. (1998). Production Functions: The Search for Identification. In R. Strøm (Ed.), Econometrics and Economic Theory in the Twentieth Century: The Ragnar Frisch Centennial Symposium (pp. 169-203). Cambridge; New York and Melbourne: Cambridge University Press.

Hadi, A. S. (1992). Identifying Multiple Outliers in Multivariate Data. Journal of the Royal Statistical Society, Series (B), 54, 761-771.

. (1994). A Modification of a Method for the Detection of Outliers in Multivariate Samples. Journal of the Royal Statistical Society, Series (B), 56, 393-396.

Hakola, T. and Uusitalo, R. (2005). Not So Voluntary Retirement Decisions? Evidence from a Pension Reform. Journal of Public Economics, 89(11-12), 2121-2136. 
Haltiwanger, J. C., Lane, J. I. and Spletzer, J. R. (1999). Productivity Differences across Employers: The Roles of Employer Size, Age, and Human Capital. American Economic Review, 89(2), 94-98.

. (2007). Wages, Productivity, and the Dynamic Interaction of Businesses and Workers. Labour Economics, forthcoming.

Hamermesh, D. S. and Pfann, G. A. (1996). Turnover and the Dynamics of Labour Demand. Economica, 63(251), 359-367.

Hellerstein, J. K. and Neumark, D. (2004). Production Function and Wage Equation Estimation with Heterogeneous Labor: Evidence from a New Matched Employer-Employee Data Set. NBER, Working Paper No. 10325.

Hellerstein, J. K., Neumark, D. and Troske, K. R. (1999). Wages, Productivity, and Worker Characteristics: Evidence from Plant-Level Production Functions and Wage Equations. Journal of Labor Economics, 17(3), 409-446.

Hutchens, R. (1986). Delayed Payment Contracts and a Firm's Propensity to Hire Older Workers. Journal of Labor Economics, 4(4), 439-457.

. (1988). Do Job Opportunities Decline with Age? Industrial and Labor Relations Review, 42(1), 89-99.

Ilmakunnas, P. and Maliranta, M. (2005). Technology, Labour Characteristics and Wage-Productivity Gaps. Oxford Bulletin of Economics and Statistics, 67(5), 623-644.

Ilmakunnas, P., Maliranta, M. and Vainiomäki, J. (2004). The Roles of Employer and Employee Characteristics for Plant Productivity. Journal of Productivity Analysis, 21, 249-276.

_. (2005). Worker Turnover and Productivity Growth. Applied Economics Letters, 12(7), 395-398.

Jovanovic, B. (1979). Job Matching and the Theory of Turnover. Journal of Political Economy, 87(5), 972-990.

Kanazawa, S. (2003). Why Productivity Fades with Age: The Crime-Genius Connection. Journal of Research in Personality, 37, 257-272.

Kyyrä, T. and Wilke, R. A. (2007). Reduction in the Long-Term Unemployment of the Elderly: A Success Story from Finland. Journal of the European Economic Association, 5(2007), 154182.

Lane, J. I., Isaac, A. G. and Stevens, D. W. (1996). Firm Heterogeneity and Worker Turnover. Review of Industrial Organization, 11(3), 275-291.

Lazear, E. P. (1979). Why Is There Mandatory Retirement? Journal of Political Economy, 87(6), 1261-1284.

(1990). Job Security Provisions and Employment, Quarterly Journal

of Economics, 105(3): 699-726. Quarterly Journal of Economics 105(3), 699-726.

Levinsohn, J. and Petrin, A. (2003). Estimating Production Functions Using Inputs to Control for Unobservables. Review of Economic Studies, 70(2), 317-341.

Maliranta, M. (1997). Plant-Level Explanations for the Catch-up Process in Finnish Manufacturing: A Decomposition of Aggregate Labour Productivity Growth. In S. Laaksonen (Ed.), The Evolution of Firms and Industries. International Perspectives (pp. 352-369). Helsinki: Statistics Finland.

Maliranta, M. and Ilmakunnas, P. (2005). Decomposing Productivity and Wage Effects of IntraEstablishment Labor Restructuring. ETLA, Discussion Papers No. 993. Helsinki.

Malmberg, B., Lindh,T. and Halvarsson, M. (2005). Productivity Consequences of Workforce Ageing Stagnation or a Horndal Effect? : Institute for Futures Studies, Arbetsrapport No. 2005:17. 
Moretti, E. (2004). Workers' Education, Spillovers, and Productivity: Evidence from Plant-Level Production Functions. American Economic Review, 94(3), 656-690.

Nelson, R. R. and Phelps, E. S. (1966). Investment in Humans, Technological Diffusion, and Economic Growth. American Economic Review Papers and Proceedings LVI, 69-75.

OECD. (2006). Live Longer, Work Longer. Paris: OECD.

Olley, G. S. and Pakes, A. (1996). The Dynamics of Productivity in the Telecommunications Equipment Industry. Econometrica, 64(6), 1263-1297.

Siebert, S. W., Zubanov, N., Chevalier, A. and Viitanen, T. (2006). Labour Turnover and Labour Productivity in a Retail Organization. IZA, Discussion Paper No. 2322.

Skirbekk, V. (2004). Age and Individual Productivity: A Literature Survey. In G. Feichtinger (Ed.), Vienna Yearbook of Population Research 2004 (pp. 133-153). Vienna: Austrian Academy of Sciences Press.

Vainiomäki, J. (1999). Technology and Skill Upgrading: Results from Linked Worker-Plant Data for Finnish Manufacturing. In J. Haltiwanger, J. Lane, J. R. Spletzer, J. J. M. Theuwes \& K. R. Troske (Eds.), The Creation and Analysis of Employer-Employee Matched Data (pp. 115145). Amsterdam; New York and Oxford: Elsevier Science, North-Holland.

van Ark, B., Inklaar, R. and McGuckin, R. (2003). ICT and Productivity in Europe and the United States. Where Do the Differences Come From? CESifo Economic Studies, 49(3), 295-318.

Williams, C. R. and Parrack, L. (1994). Another Look at the Relationship between Performance and Voluntary Turnover. Academy of Management Journal, 37(2), 269-298. 


\section{APPENDIX}

Table A.1. The number of observations in the estimation sample by branches

\begin{tabular}{|c|c|c|c|}
\hline Industry | & Freq. & Percent & Cum. \\
\hline . & -- & 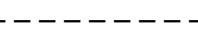 & $-\cdots$ \\
\hline (10-14) Mining and quarrying & 73 & 0.39 & 0.39 \\
\hline (15-16) Food, bev. \& tob. & 626 & 3.32 & 3.71 \\
\hline (17-18) Textiles \& products & 409 & 2.17 & 5.88 \\
\hline (19) Leather \& products & 91 & 0.48 & 6.36 \\
\hline (20) Wood \& products & 519 & 2.75 & 9.12 \\
\hline (21-22) Paper \& printing & 921 & 4.89 & 14.00 \\
\hline (23) Coke and petroleum & 6 & 0.03 & 14.03 \\
\hline (24) Chemicals & 250 & 1.33 & 15.36 \\
\hline (25) Rubber \& plastic & 369 & 1.96 & 17.32 \\
\hline (26) Non-metallic mineral & 305 & 1.62 & 18.94 \\
\hline (27-28) Basic metals & 1,451 & 7.70 & 26.63 \\
\hline (29) Machinery and equip. & 1,101 & 5.84 & 32.48 \\
\hline (30-33) Electrical equip. & 592 & 3.14 & 35.62 \\
\hline (34-35) Transport equipment & 316 & 1.68 & 37.29 \\
\hline (36-37) Manufacturing n.e.c. & 505 & 2.68 & 39.97 \\
\hline (40-41) Public utilities & 250 & 1.33 & 41.30 \\
\hline (45) Construction & 1,925 & 10.21 & 51.51 \\
\hline (50-52) Wholesale and retail trade & 4,642 & 24.63 & 76.14 \\
\hline (55) Hotels \& restaurants & 594 & 3.15 & 79.29 \\
\hline (60-64) Transportation & 1,305 & 6.92 & 86.22 \\
\hline (65-74) Other business & 2,055 & 10.90 & 97.12 \\
\hline (85\&92-93) Misc. services | & 543 & 2.88 & 100.00 \\
\hline Total & 18,848 & 100.00 & \\
\hline
\end{tabular}


Table A.2. Median regression estimates of the profit equation

\begin{tabular}{|c|c|c|c|}
\hline & $\begin{array}{c}\text { Productivity } \\
\text { (1) }\end{array}$ & $\begin{array}{c}\text { Wages } \\
\text { (2) }\end{array}$ & $\begin{array}{l}\text { Profits } \\
\text { (3) }\end{array}$ \\
\hline Hired -30 yrs. & $\begin{array}{l}-0.107^{* * *} \\
(0.019)\end{array}$ & $\begin{array}{l}-0.091^{* * *} \\
(0.011)\end{array}$ & $\begin{array}{c}0.000 \\
(0.014)\end{array}$ \\
\hline Hired 31-50 yrs. & $\begin{array}{l}-0.006 \\
(0.020)\end{array}$ & $\begin{array}{c}0.025^{* *} \\
(0.012)\end{array}$ & $\begin{array}{l}-0.057^{* * *} \\
(0.014)\end{array}$ \\
\hline Hired 51-yrs. & $\begin{array}{l}-0.189 * * * \\
(0.052)\end{array}$ & $\begin{array}{l}-\odot .065^{* *} \\
(\odot .031)\end{array}$ & $\begin{array}{l}-0.071^{*} \\
(0.037)\end{array}$ \\
\hline Separated -28 yrs. & $\begin{array}{l}-0.098^{* * *} \\
(0.020)\end{array}$ & $\begin{array}{l}-0.091^{* * *} \\
(0.012)\end{array}$ & $\begin{array}{l}0.025^{*} \\
(0.014)\end{array}$ \\
\hline Separated 29-48 yrs. & $\begin{array}{c}-0.005 \\
(0.010)\end{array}$ & $\begin{array}{c}0.035^{* * *} \\
(0.006)\end{array}$ & $\begin{array}{l}-0.042 * * * \\
(0.008)\end{array}$ \\
\hline Separated 49- yrs. & $\begin{array}{c}0.046^{*} \\
(0.028)\end{array}$ & $\begin{array}{r}-0.016 \\
(0.017)\end{array}$ & $\begin{array}{c}0.043^{* *} \\
(0.020)\end{array}$ \\
\hline Stayers 31-50 yrs. & $\begin{array}{c}0.041^{* * *} \\
(0.016)\end{array}$ & $\begin{array}{c}0.054^{* * *} \\
(\odot .0 \odot 9)\end{array}$ & $\begin{array}{l}-0.014 \\
(0.011)\end{array}$ \\
\hline Stayers 51- yrs. & $\begin{array}{r}-0.005 \\
(0.018)\end{array}$ & $\begin{array}{r}0.015 \\
(0.011)\end{array}$ & $\begin{array}{l}-0.029 * * \\
(0.013)\end{array}$ \\
\hline $\begin{array}{l}\text { Observations } \\
\mathrm{R} \text {-squared }\end{array}$ & 19236 & 19236 & 19236 \\
\hline
\end{tabular}

Note: Other variables include the initial wage and productivity levels (in logs), log-change in capital per labor, regional dummies and interactions of industry and period dummies. Employment weighted estimation. Firms with at least 10 and at most 10000 employees included. Outliers included. 
Table A.3. Productivity equation by sectors and by ICT/non-ICT division, narrow ICT definition

\begin{tabular}{|c|c|c|c|c|c|c|}
\hline \multirow{3}{*}{ Hired -30 yrs. } & \multirow{3}{*}{$\begin{array}{c}-- \text { Business } \\
\text { ICT } \\
(1) \\
-0.057 \\
(0.120)\end{array}$} & \multirow{2}{*}{$\begin{array}{l}\text { sector - - } \\
\text { non-ICT } \\
\quad(2)\end{array}$} & \multicolumn{2}{|c|}{ - - - - Industry-- - - } & \multicolumn{2}{|c|}{ - - - - -Services- - - - } \\
\hline & & & $\begin{array}{l}\text { ICT } \\
(3)\end{array}$ & $\begin{array}{c}\text { non-ICT } \\
(4)\end{array}$ & $\begin{array}{l}\text { ICT } \\
(5)\end{array}$ & $\begin{array}{c}\text { non-ICT } \\
(6)\end{array}$ \\
\hline & & $\begin{array}{l}-0.122 * * * \\
(0.045)\end{array}$ & $\begin{array}{r}0.115 \\
(0.187)\end{array}$ & $\begin{array}{r}0.059 \\
(0.075)\end{array}$ & $\begin{array}{l}-0.196 * \\
(0.101)\end{array}$ & $\begin{array}{l}-0.201^{* * *} \\
(0.055)\end{array}$ \\
\hline Hired 31-50 yrs. & $\begin{array}{c}-0.108 \\
(0.092)\end{array}$ & $\begin{array}{r}-0.045 \\
(0.046)\end{array}$ & $\begin{array}{c}-0.138 \\
(0.138)\end{array}$ & $\begin{array}{r}-0.037 \\
(0.063)\end{array}$ & $\begin{array}{c}-0.125 \\
(0.101)\end{array}$ & $\begin{array}{c}-0.099 \\
(0.061)\end{array}$ \\
\hline Hired 51 - yrs. & $\begin{array}{r}0.158 \\
(0.335)\end{array}$ & $\begin{array}{l}-0.314^{* *} \\
(0.147)\end{array}$ & $\begin{array}{r}0.548 \\
(0.432)\end{array}$ & $\begin{array}{l}-0.445^{*} \\
(0.239)\end{array}$ & $\begin{array}{l}-0.859^{* *} \\
(0.361)\end{array}$ & $\begin{array}{c}-0.141 \\
(0.144)\end{array}$ \\
\hline Separated -28 yrs. & $\begin{array}{r}0.136 \\
(0.153)\end{array}$ & $\begin{array}{l}-0.192^{* * *} \\
(0.059)\end{array}$ & $\begin{array}{r}0.047 \\
(0.251)\end{array}$ & $\begin{array}{l}-0.243^{* * *} \\
(0.087)\end{array}$ & $\begin{array}{c}0.399^{* * *} \\
(0.108)\end{array}$ & $\begin{array}{l}-0.138^{*} \\
(0.076)\end{array}$ \\
\hline Separated 29-48 yrs. & $\begin{array}{l}-0.138^{* *} \\
(0.063)\end{array}$ & $\begin{array}{c}-0.016 \\
(0.030)\end{array}$ & $\begin{array}{l}-\odot .160^{*} \\
(\odot .094)\end{array}$ & $\begin{array}{r}-0.059 \\
(0.036)\end{array}$ & $\begin{array}{r}-\odot .078 \\
(\odot .097)\end{array}$ & $\begin{array}{r}0.025 \\
(0.067)\end{array}$ \\
\hline Separated 49-yrs. & $\begin{array}{c}0.275^{*} \\
(0.152)\end{array}$ & $\begin{array}{c}0.198^{* *} \\
(\odot .091)\end{array}$ & $\begin{array}{c}0.726^{* * *} \\
(0.234)\end{array}$ & $\begin{array}{c}0.422^{* * *} \\
(0.110)\end{array}$ & $\begin{array}{c}-0.035 \\
(0.187)\end{array}$ & $\begin{array}{c}-0.039 \\
(0.143)\end{array}$ \\
\hline Satyers 31-50 yrs. & $\begin{array}{c}-0.085 \\
(0.125)\end{array}$ & $\begin{array}{r}0.035 \\
(0.042)\end{array}$ & $\begin{array}{l}-0.318^{*} \\
(0.186)\end{array}$ & $\begin{array}{r}0.017 \\
(0.057)\end{array}$ & $\begin{array}{c}0.172^{*} \\
(0.092)\end{array}$ & $\begin{array}{r}0.039 \\
(0.058)\end{array}$ \\
\hline Stayers 51- yrs. & $\begin{array}{c}-0.103 \\
(0.128)\end{array}$ & $\begin{array}{c}-0.038 \\
(0.044)\end{array}$ & $\begin{array}{l}-0.434^{* *} \\
(0.182)\end{array}$ & $\begin{array}{r}-0.027 \\
(0.063)\end{array}$ & $\begin{array}{c}0.275^{* * *} \\
(0.105)\end{array}$ & $\begin{array}{c}-0.049 \\
(0.064)\end{array}$ \\
\hline Observations & 4137 & 14711 & 2421 & 7288 & 1716 & 7423 \\
\hline R-squared & 0.260 & $\odot .253$ & $\odot .296$ & 0.316 & $\odot .231$ & 0.173 \\
\hline
\end{tabular}

Note: Other variables include the initial wage and productivity levels (in logs), log-change in capital per labor, regional dummies and interactions of industry and period dummies. Employment weighted estimation. Firms with at least 10 and at most 10000 employees included. 
Table A.4. Wage equation by sectors and by ICT/non-ICT division, narrow ICT definition

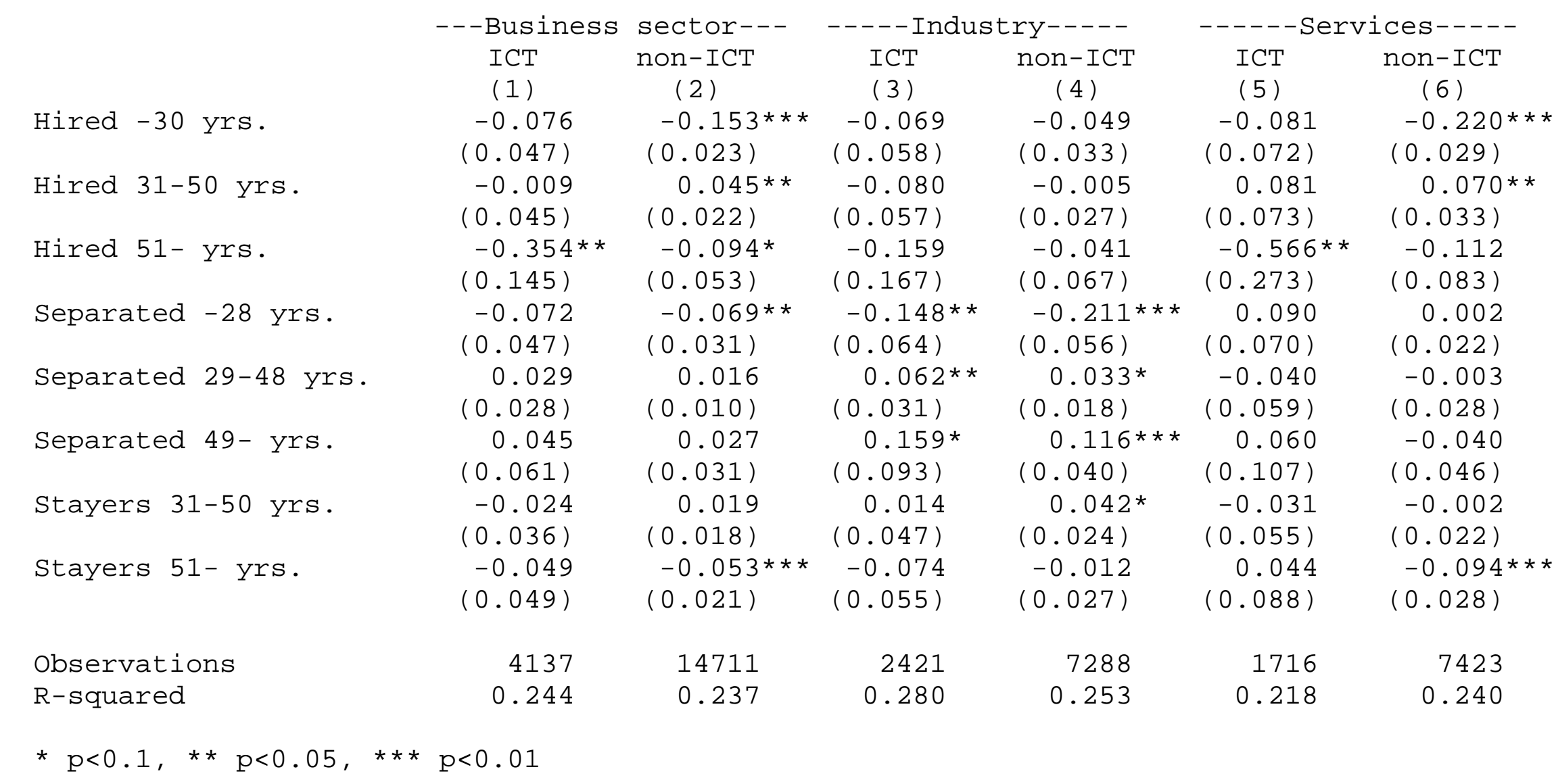

Note: Other variables include the initial wage and productivity levels (in logs), log-change in capital per labor, regional dummies and interactions of industry and period dummies. Employment weighted estimation. Firms with at least 10 and at most 10000 employees included. 
Table A.5. Profit equation by sectors and by ICT/non-ICT division, broad ICT definition

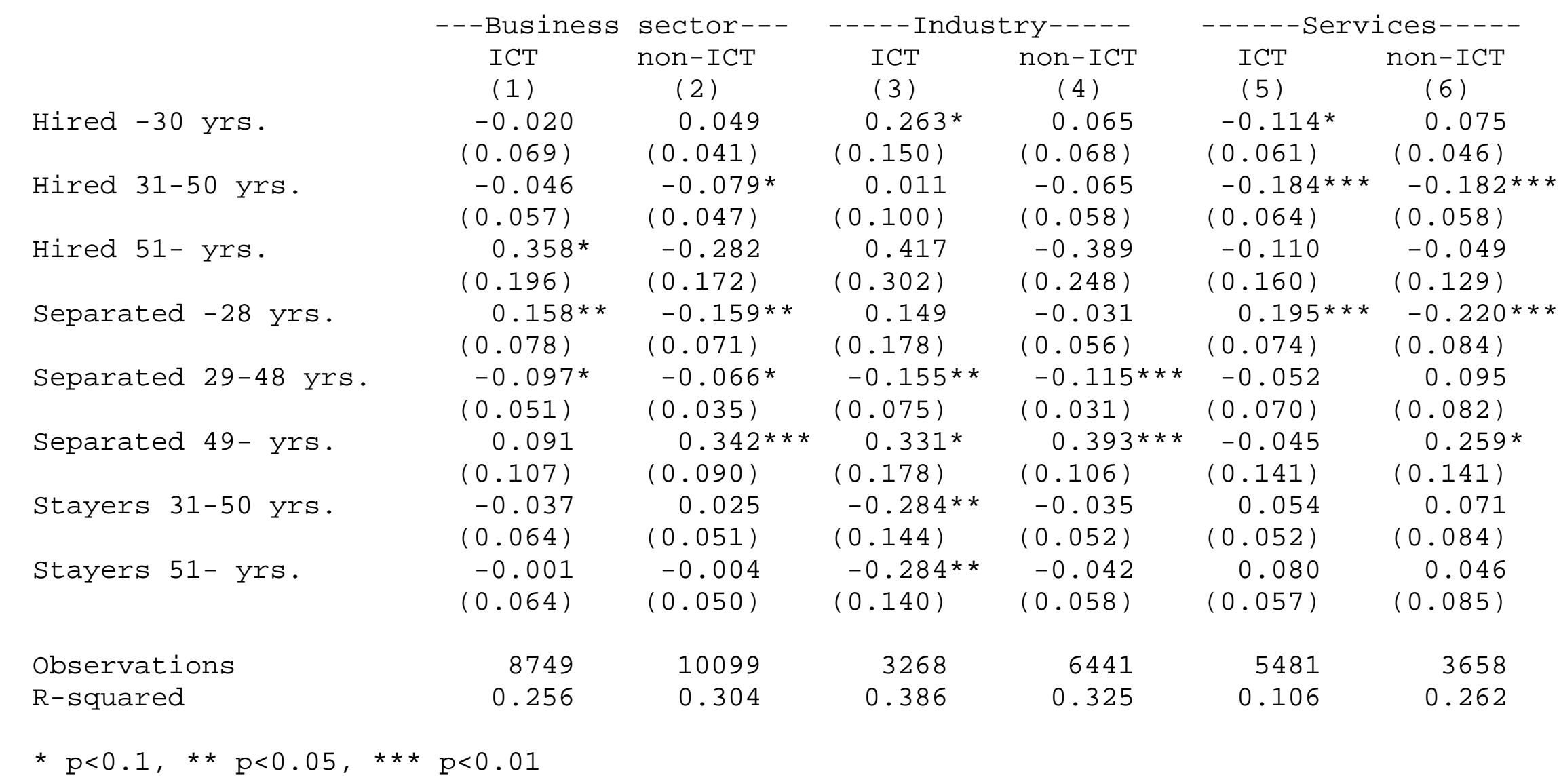

Note: Other variables include the initial wage and productivity levels (in logs), log-change in capital per labor, regional dummies and interactions of industry and period dummies. Employment weighted estimation. Firms with at least 10 and at most 10000 employees included. 
Table A.6. Profit equation by sectors and by employment growth

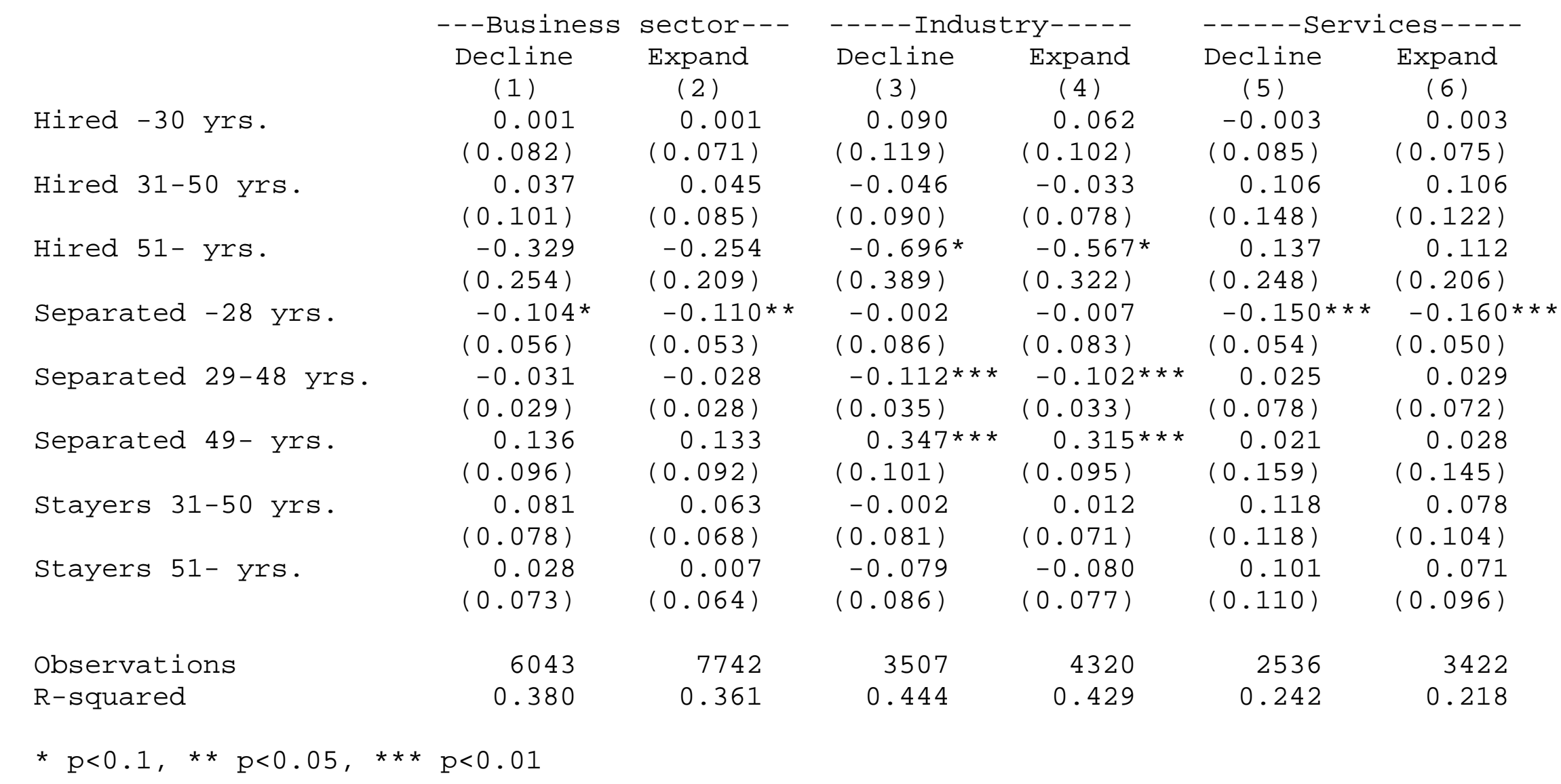

Note: Other variables include the initial wage and productivity levels (in logs), log-change in capital per labor, regional dummies and interactions of industry and period dummies. Employment weighted estimation. Firms with at least 10 and at most 10000 employees included. 


\title{
Endnotes
}

\begin{abstract}
${ }^{1}$ See “Ericsson puts age limit on redundancy” (Financial Times, April 25, 2006).
2 See “Revieving and revising Wal-Mart's benefits strategy”, Supplemental Benefits Documentation, Board of Directors retreat FY06 (http://www.nytimes.com/packages/pdf/business/26walmart.pdf). Some observers, however, argue that Wal-Mart is not as low labor cost firm as generally thought, since turnover costs are high ("WalMart's real cost of labor”, San Diego Union-Tribune, July 7, 2004).
\end{abstract}

${ }^{3}$ According to a a recent ruling of the European Court of Justice, employees with longer seniority can be paid more for the same work, if the length of service enables to do the job better. Seniority-based pay increases are therefore allowed in principle, but they are not automatically justified. The discussion on the implications of the ruling has so far concentrated on male-female wage differences and not on age-related pay differences.

${ }^{4}$ There is also some literature, where the relationship of labor turnover to firm survival is investigated, e.g. Lane et al. (1996) and Brown et al. (2006).

5 There is empirical research in management (e.g. Williams \& Parrack, 1994), and to some extent in labor economics (Bishop, 1990), where it is investigated whether it is the good or poor performers who have a higher propensity to quit or be laid off. This work explicitly addresses the issue of heterogeneity in the labor flows, but requires that there are data available on individual productivities. In contrast to this, we intend to estimate the relative productivities of various components of labor turnover.

${ }^{6}$ Maliranta (1997), Vainiomäki (1999), Maliranta and Ilmakunnas (2005) as well as Diewert and Fox (2005) have presented similar decompositions in different contexts.

7 Note that while we are using labor flows and shares of staying workers by age to explain firm performance, there is a field of literature where the determinants of hiring and employing older workers are analyzed (Hutchens, 1986, 1988; Daniel \& Heywood, 2007). Related is also the work of Aubert et al. (2006), where the impact of new technologies on the hiring and separation flows by age groups is analyzed.

${ }^{8}$ We leave out the period 1990-1994, because it was a period of a deep recession and may not be representative of the developments of labor flows and firm performance. In addition, our company data are substantially less comprehensive before the year 1995.

${ }^{9}$ These dummies also account for changes in the payroll taxes $a$, which were assumed fixed in the derivation of the formulas in Section 3.

${ }^{10}$ Moretti (2004) uses increases in the regional share of college graduates as an explanatory variable in a plantlevel production function to measure spillovers. Our use of the information on graduates is different, since we use it to form instruments to control for exogenous shifts in labor supply. Since we can disaggregate the labor flows by education, we could actually measure educational spillovers directly through the hiring flows. This is left for future work.

${ }^{11}$ More precisely, the numbers for each area are calculated by taking a weighted average of all municipalities in the area around the "central municipality". Each municipality is the "central municipality" of its labor force area. So, calculations are performed separately for each municipality so that the number of areas is equal to the number of municipalities in Finland. The weight of an adjoining municipality is the share of employees of the total number employees in the "central municipality" who have their residence in that adjoining municipality. The weight of the "central municipality" is the share of those employees in the "central municipality" who do not commute between municipalities.

12 The number of observations drops because of the reasons discussed in the text. We exclude some industries, like finance and real estate, the smallest firms, those where the linking of individuals and firms has not been successful, and some outliers.

${ }^{13}$ Note that these figures underestimate actual turnover among the employees, since e.g. hiring of an employee after the start of a two-year period and subsequent separation of the same employee before the end of the period is not included in the turnover rates.

${ }^{14}$ In the Finnish pension system the pension was until 1996 based on the last four years' pay and until 2004 on the last ten year's pay in each employment relationship. From 2005 pensions are based on annual incomes over the whole working career and are no longer tied to employment relationships. 


\footnotetext{
${ }^{15}$ Until the year 1996 it was possible for those who became unemployed at the age of 53 to be for two years on normal earnings-related unemployment compensation, then for five years on a special extension of unemployment compensation, and at the age of 60 they could retire to unemployment pension until they finally reached normal retirement age. From 1997 the starting year of the pipeline was raised to 55 years. This reform resulted in a lower unemployment risk for the age group 53-54 (Kyyrä \& Wilke, 2007). From 2005 the system has been changed so that the starting age of the pipeline is 57 and unemployment pension is no longer available for the younger cohorts. In addition to the unemployment pension system, also disability pension gives incentives for laying off older employees. The larger firms are responsible for paying the disability pension until the normal retirement age. This can be avoided, if the worker goes to the unemployment pension pipeline before possible disability.

${ }^{16}$ It should be noted that "Financial intermediation" (ISIC 65-67) industries are excluded from our estimation sample.

${ }^{17}$ See discussion in Daveri (2004).

${ }^{18}$ In a recent pension reform in Finland, the subjective right of the employees to stay at work longer has been extended to 68 years. On the other hand, the firms' possibilities for using the "unemployment pension pipeline" for laying off older workers has been limited, as the starting age of the pipeline has been increased. At the same time, the way pension levels are calculated has been changed. It is now the earnings over the whole working career rather than in the last few years that counts. The old system has included incentives for high pay at the end of the career and a fixed retirement age. This is consistent with Lazear (1979), although the system has been based on a mix of centralized negotiations between labor unions, employer organizations and the government, and firm-level wage setting.
} 


\section{E L I N K E I N O E L ÄM Ä N T UTK I M U S L A I T O S THE RESEARCH INSTITUTE OF THE FINNISH ECONOMY LÖNNROTINKATU 4 B, FIN-00120 HELSINKI}

Puh./Tel. (09) 609900

Int. 358-9-609 900

http://www.etla.fi
Telefax (09) 601753

Int. 358-9-601 753

\section{KESKUSTELUAIHEITA - DISCUSSION PAPERS ISSN 0781-6847}

Julkaisut ovat saatavissa elektronisessa muodossa internet-osoitteessa:

http://www.etla.fi/finnish/research/publications/searchengine

No 1060 OLLI-PEKKA RUUSKANEN, Time Use during the Parental Leave and the Return to Employment. 30.12.2006. $32 \mathrm{p}$.

No 1061 VILLE KAITILA - NUUTTI NIKULA - JUDIT KARSAI, Suomalaiset yritykset Tšekin, Slovakian, Unkarin ja Slovenian markkinoilla. 18.12.2006. $90 \mathrm{s.}$

No 1062 NIKU MÄÄTTÄNEN - PANU POUTVAARA, Should Old-age Benefits be Earnings Tested? 18.12.2006. $24 \mathrm{p}$.

No 1063 AIJA LEIPONEN - CONSTANCE E. HELFAT, When Does Distributed Innovation Activity Make Sense? Location, Decentralization, and Innovation Success, 20.12.2006. 32 p.

No 1064 CHRISTOPHER PALMBERG - MIKA PAJARINEN - TUOMO NIKULAINEN, Transferring Science-Based Technologies to Industry - Does Nanotechnology make a Difference? 04.01.2007. $64 \mathrm{p}$.

No 1065 NIKU MÄÄTTÄNEN - MIKA MALIRANTA, T\&K-toiminnan verokannustimet ja yritysdynamiikka. 04.01.2007. $23 \mathrm{~s}$.

No 1066 TARMO VALKONEN, Tutkimus- ja tuotekehitysinvestointien verotuki. 11.01.2007. 24 s.

No 1067 TERTTU LUUKKONEN - MARI MAUNULA, Non-financial Value-added of Venture Capital: A Comparative Study of Different Venture Capital Investors. 18.01.2007. 26 p.

No 1068 MARKKU MAULA, Verokannustimet yksityishenkilöiden riskipääomasijoitusten aktivoinnissa. 22.01.2007. $40 \mathrm{~s}$.

No 1069 OLAVI RANTALA, Palvelualojen kilpailu ja hinnanmuodostus kansainvälisessä vertailussa. 22.01.2007. $40 \mathrm{~s}$.

No 1070 JYRKI ALI-YRKKÖ, Ulkoistukset Suomen teollisuusyrityksissä - onko toimialalla merkitystä? 12.02.2007. $15 \mathrm{~s}$.

No 1071 JYRKI ALI-YRKKÖ, Tuotannon ja T\&K-toiminnan ulkoistaminen - motiivit ja onnistuminen. 12.02.2007. $16 \mathrm{~s}$.

No 1072 CHRISTOPHER PALMBERG, Nanoteknologiastako seuraava yleiskäyttöinen teknologia? Havaintoja Suomen näkökulmasta. 08.02.2007. 25 s.

No 1073 JUKKA LASSILA - TARMO VALKONEN, Longevity Adjustment of Pension Benefits. 12.02.2007. $20 \mathrm{p}$.

No 1074 KARI E.O. ALHO - NUUTTI NIKULA, Productivity, Employment and Taxes - A Svar Analysis of the Trade-offs and Impacts. 22.02.2007. 19 p. 
No 1075 RAINE HERMANS - MARTTI KULVIK, Simulaatio lääkekehitysalan kannattavuudesta ja riskeistä. 26.02.2007. 25 s.

No 1076 TERHI HAKALA - OLLI HALTIA - RAINE HERMANS - MARTTI KULVIK - HANNA NIKINMAA - ALBERT PORCAR-CASTELL - TIINA PURSULA, Biotechnology as a Competitive Edge for the Finnish Forest Cluster. 26.02.2007. 76 p.

No 1077 RITA ASPLUND, Finland: Decentralisation Tendencies within a Collective Wage Bargaining System. 02.03.2007. 31 p.

No 1078 PAVEL FILIPPOV - VLAD YURKOVSKY, Essay on Internationalisation Potential of Northwest Russian and Finnish Energy Clusters. 20.03.2007. 36 p.

No 1079 MARKKU KOTILAINEN, Determinants of Finnish-Russian Economic Relations. 22.03.2007. 39 p.

No 1080 JYRKI ALI-YRKKÖ - MIKA PAJARINEN - PETRI ROUVINEN - PEKKA YLÄ-ANTTILA, Family Businesses and Globalization in Finland. 03.04.2007. 35 p.

No 1081 JYRKI ALI-YRKKÖ, Ulkomaalaisomistuksen vaikutus yritysten kasvuun. 29.03.2007. 24 s.

No 1082 MIKKO KETOKIVI - JYRKI ALI-YRKKÖ, Determinants of Manufacturing-R\&D Colocation. 30.03.2007. 28 p.

No 1083 VILLE KAITILA, Suomen ulkomaankaupan erikoistuminen - keiden kanssa kilpailemme? 05.04.2007. $25 \mathrm{~s}$.

No 1084 MIKKO MÄKINEN, CEO Compensation, Firm Size and Firm Performance: Evidence from Finnish Panel Data. 30.03.2007. 38 p.

No 1085 MIKKO MÄKINEN, Do Stock Option Schemes Affect Firm Technical Inefficiency? Evidence from Finland. 30.03.2007. 26 p.

No 1086 CHRISTOPHER PALMBERG, Modes, Challenges and Outcomes of Nanotechnology Transfer A Comparative Analysis of University and Company Researchers. 05.04.2007. 33 p.

No 1087 VILLE KAITILA, Free Trade between the EU and Russia: Sectoral Effects and Impact on Northwest Russia. 05.04.2007. 23 p.

No 1088 PAAVO SUNI, Oil Prices and The Russian Economy: Some Simulation Studies with NiGEM. 16.04.2007. $15 \mathrm{p}$.

No 1089 JUKKA LASSILA - NIKU MÄÄTTÄNEN - TARMO VALKONEN, Vapaaehtoinen eläkesäästäminen tulevaisuudessa. 16.04.2007. 38 s.

No 1090 VILLE KAITILA, Teollisuusmaiden suhteellinen etu ja sen panosintensiivisyys. 25.04.2007. $31 \mathrm{~s}$.

No 1091 HELI KOSKI, Private-collective Software Business Models: Coordination and Commercialization via Licensing. 26.04.2007. 24 p.

No 1092 PEKKA ILMAKUNNAS - MIKA MALIRANTA, Aging, Labor Turnover and Firm Performance. 02.05.2007. $40 \mathrm{p}$.

Elinkeinoelämän Tutkimuslaitoksen julkaisemat "Keskusteluaiheet" ovat raportteja alustavista tutkimustuloksista ja väliraportteja tekeillä olevista tutkimuksista. Tässä sarjassa julkaistuja monisteita on mahdollista ostaa Taloustieto Oy:stä kopiointi- ja toimituskuluja vastaavaan hintaan.

Papers in this series are reports on preliminary research results and on studies in progress. They are sold by Taloustieto Oy for a nominal fee covering copying and postage costs. 